\title{
Top management team faultlines and firm performance: examining the CEO-TMT interface
}

Article

Accepted Version

Creative Commons: Attribution-Noncommercial-No Derivative Works 4.0

Georgakakis, D., Greve, P. and Ruigrok, W. (2017) Top management team faultlines and firm performance: examining the CEO-TMT interface. The Leadership Quarterly, 28 (6). pp. 741-758. ISSN 1048-9843 doi:

https://doi.org/10.1016/j.leaqua.2017.03.004 Available at https://centaur.reading.ac.uk/69573/

It is advisable to refer to the publisher's version if you intend to cite from the work. See Guidance on citing.

To link to this article DOI: http://dx.doi.org/10.1016/j.leaqua.2017.03.004

Publisher: Elsevier

All outputs in CentAUR are protected by Intellectual Property Rights law, including copyright law. Copyright and IPR is retained by the creators or other copyright holders. Terms and conditions for use of this material are defined in the End User Agreement.

www.reading.ac.uk/centaur 
Central Archive at the University of Reading

Reading's research outputs online 
TOP MANAGEMENT TEAM FAULTLINES AND FIRM PERFORMANCE:

EXAMINING THE CEO-TMT INTERFACE

\author{
DIMITRIOS GEORGAKAKIS a * \\ e-mail: dimitrios.georgakakis@unisg.ch \\ PEDER GREVE ${ }^{b}$ \\ e-mail: peder.greve@henley.ac.uk \\ WINFRIED RUIGROK ${ }^{\mathrm{a}}$ \\ e-mail: winfried.ruigrok@unisg.ch \\ ${ }^{a}$ University of St. Gallen \\ Research Institute for International Management \\ Dufourstrasse 40a \\ CH-9000 St. Gallen, Switzerland \\ Tel: (+41)-71-2242986 \\ Fax: (+41)-71-2242447 \\ ${ }^{\mathrm{b}}$ Henley Business School, University of Reading \\ International Business and Strategy \\ Henley-on-Thames, Oxon, RG9 3AU, UK \\ Tel: (+44)-1491-414-522 \\ * Corresponding author
}

- Accepted for publication in The Leadership Quarterly - 


\title{
TOP MANAGEMENT TEAM FAULTLINES AND FIRM PERFORMANCE: \\ EXAMINING THE CEO-TMT INTERFACE
}

\begin{abstract}
Prior research indicates that the relationship between top management team (TMT) faultlines and firm performance is equivocal. We shed new light on this topic by highlighting the moderating role of the CEO-TMT interface. Analyzing data from large international firms over the period 2005-2009 (347 firm-year combinations), we find that the performance effect of knowledge-based TMT faultlines is significantly altered when the leader of the TMT (i.e., the CEO): (a) socio-demographically resembles incumbent executives, (b) possesses a diverse career background, and (c) shares common socialization experience with other TMT members. Overall, our research reveals that different dimensions of the CEO-TMT interface play a pivotal role in determining the performance effects of knowledge-based TMT subgroups. Implications for upper echelons theory, team diversity, and strategic leadership research are discussed.
\end{abstract}

Keywords: Strategic leadership; Top management teams; CEOs; Upper echelons; Faultlines; Firm performance; CEO-TMT interface

Acknowledgements: We thank the Associate Editor, Michael Cole, and three anonymous reviewers for their constructive comments throughout the blind review process. We also thank Tine Buyl, Bert Cannella, Tobias Dauth, Georg Guttmann, Simon Peck, Marko Reimer, as well as participants of the $7^{\text {th }}$ EIASM workshop on Top Management Teams and Business Strategy (Groningen) for their valuable comments on earlier drafts. The authors acknowledge support of the Swiss National Science Foundation (SNSF), Research Grant - 100018_140455. 


\section{Introduction}

As strategic leadership research accumulates, scholars increasingly recognize the importance of understanding how and under what conditions different forms of top management team (TMT) diversity impact organizations (Finkelstein, Hambrick \& Cannella, 2009). A key form of diversity relevant to TMT functioning and performance is the presence of knowledge-based faultines - defined as the alignment of team members' experiential characteristics that splits the team into homogeneous subgroups of knowledge and expertise (Bezrukova, Jehn, Zanutto \& Thatcher, 2009; Crawford \& LePine, 2013). This type of subgroup formation is relevant for TMTs, as it represents the informational clusters that "form according to specialized knowledge" of team members (Carton \& Cummings, 2012: 447), and influences how top managers make strategic decisions to impact firm outcomes (Hutzschenreuter \& Horstkotte, 2013; Ndofor, Sirmon, \& He, 2014).

While the importance of knowledge-based faultlines has been widely recognized, their performance implications are not clearly established in the literature. On the one hand, some studies argue that the presence of knowledge-based subgroups increases the information processing capacity of the team, and promotes innovation (Xie, Wang \& Qi, 2015), learning (Gibson \& Vermeulen, 2003), and high performance (Hutzschenreuter \& Horstkotte, 2013; Ndofor et al., 2014). In direct contrast, another stream of research posits that the impact of knowledge-based faultlines is predominantly negative (Bezrukova, Jehn, Thatcher, \& Spell, 2012), as the resulting factions between team members generate knowledge fragmentation that impairs team functioning, and results in low performance (Li \& Hambrick, 2005). In their theory of subgroups, Carton and Cummings (2012) acknowledge this duality of insights, and suggest that the presence of knowledge-related factions in a team can simultaneously trigger beneficial as well as detrimental effects. They also stress that in order to reduce the costs and realize the potential benefits of knowledge-based faultlines, firms need to attain a balance 
"between having alternative sources of knowledge available and finding a common ground in order to synthesize that knowledge" on a shared platform (Carton \& Cummings, 2012: 447).

In the context of TMTs, we argue that such a shared platform of knowledge-integration can be established at the interface between the CEO, who is the leader and "integrator" of the executive group (Buyl, Boone, Hendriks \& Matthyssens, 2011: 170; see also: Carmeli, Schaubroeck, \& Tishler, 2011; Ling, Simsek, Lubatkin, \& Veiga, 2008), and the other TMT members. Traditionally, upper echelons research has focused on the effects of the TMT as a single unit - implicitly treating the CEO as equally powerful and influential as other top managers (Hambrick \& Mason, 1984). However, a growing body of strategic leadership research has criticized this approach by stressing that the different roles and impact of the CEO and the rest of the TMT should be taken into consideration (e.g., Cannella \& Holcomb, 2005; Cao, Simsek, \& Zhang, 2010; Friedman, Carmeli, \& Tishler, 2016; Hambrick, 1994; Peterson, Smith, Mortorana, \& Owens, 2003). The key theoretical premise of this stream of research is that power is not equally distributed among members of the dominant coalition (Cannella \& Holcomb, 2005), and that the CEO - as the most powerful executive leader - has a disproportionate influence on the TMT's functioning, output, and performance (Carmeli, Tishler, \& Edmonson, 2012; Klimoski \& Koles, 2001). This logic has led scholars to argue that research on the CEO-TMT interface can help to resolve debates and shortcomings in the extant strategic leadership literature about the direct effects of TMT composition on firm outcomes (Cannella \& Holcomb, 2005; Simsek, Jansen, Minichilli, \& Escriba-Esteve, 2015).

In this study, we draw on extant research on the CEO-TMT interface to argue that the performance effects of knowledge-based TMT subgroups depend on the CEO-TMT interactional context. According to the notion of crosscutting diversity, individuals who can act as effective integrators in teams with subgroups are those who: (a) have a powerful leadership position in the group (Crawford \& LePine, 2013), and (b) share common attributes with different intra-team subgroups and can therefore establish cross-subgroup identification (Mäs, 
Flache, Takàcs, \& Jehn, 2013). Based on this notion, we theorize that the relationship between knowledge-based TMT subgroups and firm performance is influenced by three forms of the CEO-TMT interface: the relational interface (CEO-TMT social similarity), the informational interface (CEO experience variety), and the socialization interface (CEO-TMT shared experience). As we argue, CEOs with crosscutting attributes can act as bridge-builders who can unify the diverse knowledge of TMT subgroups, and translate this knowledge into desirable performance consequences. We test our framework using data from large international firms over the period 2005 to 2009.

Our study makes several contributions. First, it takes a step toward the resolution of the theoretical debate over whether knowledge-based subgroup formation in strategic leadership teams is beneficial, or detrimental for organizations (Ndofor et al., 2014). We theoretically argue and empirically demonstrate that the trade-off between the benefits and costs of knowledge-based faultlines significantly vary with the ability of the leader to develop a common platform of knowledge integration between subgroups. In this regard, our work responds to calls for linking the team diversity and leadership fields, by examining how the impact of knowledge-based faultlines is influenced by the attributes and background of the group's leader (Gratton, Voigt, \& Erickson, 2007; Meyer, Shemla, Li, \& Wegge, 2015).

Second, the study contributes to our understanding of the relationship between TMT composition and firm performance within the upper echelons research tradition. It confirms that focusing on the CEO-TMT interface is an essential step to accurately gauge the effects of TMT configuration on organizational outcomes (Cannella \& Holcomb, 2005; Klimoski \& Koles, 2001). Our findings imply that the relational (CEO-TMT similarity), informational (CEO experience variety), and socialization (CEO-TMT shared experience) interface between the CEO and other TMT members plays a key role in affecting the performance implications of knowledge-based TMT subgroups. Thus, our research corroborates the notion that modeling the different dimensions of the CEO-TMT interface helps to enhance the explanatory power of 
upper echelons theory (Buyl et al., 2011; Hambrick, 1994). It also responds to the calls for conceptualizing strategic leadership as a "shared activity" (Hmieleski, Cole, \& Baron, 2012: 1489), by examining how the collective interactions between the CEO and the rest of the TMT are ultimately reflected in firm-level outcomes (Hambrick, 2007: 334).

Third, by focusing on the effects of faultlines, our work highlights the importance of diversity as separation (Harrison \& Klein, 2007), and its effects on team functioning and firm outcomes (Cooper, Patel, \& Thatcher, 2014). According to Harrison and Klein (2007), teams with strong subgroups often experience separation among team members that, in turn, promotes behavioral disintegration (Li \& Hambrick, 2005) and low performance (Lau \& Murnighan, 1998). In such teams, an integrative force is required to minimize fragmentation processes between knowledge subgroups (Carton \& Cummings, 2012). Conceptualizing diversity as faultlines therefore allows us to examine the integrative role of the leader in teams that experience integration challenges owing to the presence of informational subgroups (Harrison \& Klein, 2007; Meyer \& Glenz, 2013; Thatcher \& Patel, 2012). In this regard, our work highlights the importance of understanding how different forms of diverse TMT composition impact team- and firm-level outcomes (van Knippenberg, Dawson, West, \& Homan, 2011).

Finally, our study offers practical implications about the leader-team compositional factors that influence the relationship between TMT faultlines and firm performance. Based on our empirical findings, we identify a set of parameters that firms should consider in order to attain a CEO-TMT 'fit' and generate underlying leadership processes of knowledge integration in TMTs with informational subgroups. The paper concludes with suggestions on how future research should move forward to shed light on the micro-level CEO-TMT leadership processes (e.g., shared leadership, leader-member information exchange), and thus move "toward a more realistic view" of how strategic leaders interdependently - and interactively - impact organizations (Cannella \& Monroe, 1997: 213). 


\section{Theory and Hypotheses}

\subsection{The CEO-TMT interface in strategic leadership research}

Over the last decades, upper echelons theory has been prominent in the integration of the strategy and leadership fields, providing researchers with a theoretical base to examine the impact of strategic leadership on firm outcomes (Finkelstein et al., 2009). Rooted in the behavioral theory of the firm (Cyert \& March, 1963), the upper echelons perspective suggests that the effects of strategic leaders on organizations can be adequately assessed based on the collective attributes of the entire executive group, rather than based on the characteristics of each top manager separately (Hambrick \& Mason, 1984). This assumption is based on the notion that power is equally distributed among members of the dominant coalition (Cyert \& March, 1963), and has inspired a wealth of empirical studies to assess the impact of the aggregated top management group - by treating the CEO as equally powerful and influential as other executives (Finkelstein et al., 2009).

While the value of looking at the overall top management group is not disputed, scholars have argued that a closer look at the interaction between the leader of the group (i.e., the CEO) and the rest of the TMT can contribute to the development of upper echelons theory (Cannella \& Holcomb, 2005; Hambrick, 1994; Klimoski \& Koles, 2001). From a strategic leadership perspective, the CEO is the most central strategic leader of the organization (Jackson, 1992). CEOs are responsible not only for composing the TMT by hiring and firing other top managers (Finkelstein et al., 2009), but also for orchestrating the leadership and behavioral processes through which TMT composition impacts firm outcomes (Cannella \& Holcomb, 2005). Indeed, as early as 1992, Jackson pointed out that a key paradox in upper echelons research is that it frequently treats the TMT as a monolithic whole, and thus disregards the distinct role of the CEO as the most powerful executive leader who has "the potential to neutralize both beneficial and debilitating composition effects" (Jackson, 1992: 371). Following this remark, Hambrick (1994: 180) acknowledged this limitation in the upper echelons literature by stressing that: 
"Perhaps out of a zeal to move away from undue focus on the single top executive [...] there has been a tendency in [top management team] research to simply include the CEO as a member of the group, averaging in his or her characteristics in establishing overall group characteristics. Yet, everyday observation and a wealth of related literature indicates that the top group leader has a disproportionate, sometimes nearly dominating influence, on the group's various characteristics and outputs."

Prompted by this observation, an increasing number of empirical studies have turned their focus from the aggregate TMT, to the interface between the CEO and other TMT members. The fundamental thesis of this stream of research is that neither a narrow focus on single CEOs, nor a simple aggregation of TMT characteristics can adequately capture the complex effect of top managers on organizations (Carmeli et al., 2012; Ling et al., 2008; Peterson et al., 2003). Instead, a focus on the interaction - or the common boundary - between the CEO and the rest of the TMT is needed to resolve open questions in the field of strategic leadership (Cannella \& Holcomb, 2005; Cao et al., 2010; Yukl, 2008).

A hitherto unresolved question in this field of research is how to reduce fragmentation disadvantages and extract potential benefits from TMT experiential diversity (Buyl et al., 2011) and faultlines (Cooper et al., 2014). Studies in this area have defined knowledge-based faultlines as the alignment of team members along multiple experience-related characteristics (e.g., Carton \& Cummings, 2012; van Knippenberg et al., 2011). This type of TMT composition presents the company with opportunities to combine and generate knowledge, to learn across subgroups, and to increase the overall performance of the TMT and the organization (Hutzschenreuter \& Horstkotte, 2013). Meanwhile, the effect of TMT knowledge factions depends on the establishment of a common platform that enables exchange and integration of information across subgroups (Carton \& Cummings, 2012). In contrast with conceptualizations of diversity as variety or disparity, teams with strong knowledge faultlines face separation and disintegration challenges that can hinder team functioning (Harrison \& Klein, 2007; Cooper et 
al., 2014). Without an integrative leadership force, members of different knowledge subgroups are likely to use their diverse experience to pursue conflicting objectives, producing knowledge fragmentation and low performance (Bezrukova et al., 2012; Lau \& Murnighan, 1998). In this study, we therefore focus on the effect of knowledge-based TMT faultlines as a key form of diversity that poses significant knowledge-integration challenges to executive teams.

\subsection{Knowledge-based TMT faultlines}

Recent reviews and meta-analyses underscore the value of contextualizing diversity in organizational research, by suggesting that the impact and relevance of different diversity dimensions (experiential versus socio-demographic diversity) are contingent upon the contextual conditions under which a team operates (Joshi \& Roh, 2009; van Knippenberg, de Dreu, \& Homan, 2004). This perspective has been echoed in the area of faultlines (Thatcher \& Patel, 2012). In their theory of subgroups, Carton and Cummings (2012) argue that the degree to which knowledge-based faultlines lead to subgroup formation is determined by the taskrelated conditions surrounding the team. As they emphasize, "subgroups emerge when faultlines are activated by exogenous factors. [...] If faultlines are not activated, they 'lie dormant' and do not lead to subgroup formation" (Carton \& Cummings, 2012: 449). For example, while in environments with low informational demands knowledge splits in a team are likely to stay inactive, under conditions with high informational requirements and task complexity knowledge-based subgroups are most likely to turn from dormant to active - and thereby influence team dynamics, processes, and performance (Cooper et al., 2014).

Accordingly, in this study we examine the impact of knowledge-based subgroups within a context of extensive informational and global leadership requirements - in TMTs of large international firms (Carpenter, Sanders, \& Gregersen, 2001) - and focus on two dimensions of executives' knowledge that are likely to trigger subgroup formation within this context; namely the functional and international experience of TMT members. Indeed, extant strategic 
leadership research has argued that functional background and international experience are two interdependent, yet distinct sources of knowledge that are critical for the effective leadership of: (a) the various functional domains of large international firms (e.g. production, marketing etc.), and (b) the challenges facing such firms in managing these domains across different country-level settings (Cannella, Park, \& Lee, 2008; Daily, Certo, \& Dalton, 2000; Dragoni, Oh, Tesluk, Moore, VanKatwyk, \& Hazucha, 2014; Roth, 1995). To effectively deal with the multifunctional and multicountry challenges facing large international organizations, executive teams are likely to develop structures of knowledge specialization - activating the development of subgroup formation in functional and international expertise (Guadalupe, Li, \& Wulf, 2014; Polzer, Crisp, Jarvenpaa, \& Kim, 2006). Given the argument that organizations are reflections of the background of TMT members (Hambrick \& Mason, 1984), such knowledge-based subgroup formation can significantly affect strategic decision making and firm-level financial outcomes (van Knippenberg et al., 2011).

Our two-dimensional conceptualization of knowledge-based faultlines is designed to capture both the advantages and disadvantages of task-related subgroup formation. Scholars contend that functional background diversity represents a valid indicator of executives' ability to process and utilize task-relevant information, and effectively allocate resources within and across business domains (Bunderson, 2003; Roth, 1995). In addition, research has stressed that international experience diversity indicates the ability of executives to process information from a variety of cultural settings, coordinate dispersed activities, recognize market adaptation needs, and distribute resources across locations (Daily et al., 2000; Fitzsimmons \& Callan, 2016). Thus, faultlines in functional and international experience can enhance the diverse information processing capacity of the strategic leadership group - enabling the TMT to effectively respond to the demands of strategic complexity (Carpenter et al., 2001).

However, while faultlines in functional and international background help to process diverse information, achieve efficiency gains, and respond to global adaptation needs, they are 
predominantly associated with process costs, and knowledge-fragmentation challenges (Lau \& Murnighan, 1998) that prevent the informational and performance benefits of subgroup formation from materializing (Bezrukova et al., 2012; Polzer et al., 2006). For example, studies show that differences in TMT members' functional background and international experience are associated with divergent mental models, limited information-sharing and conflicting objectives, which negatively affect TMTs' decision-making quality and performance (Dahlin, Weingart \& Hinds, 2005; Polzer et al., 2006). Such dynamics are likely to trigger knowledge fragmentation between subgroups, generate an us versus them behavior in the TMT, and thereby result in low performance.

\subsection{Modeling the CEO-TMT interface}

As shown in Figure 1, our framework starts with the premise that the performance effects of knowledge-based TMT subgroups are influenced by the CEO-TMT interface. Given the key role of the CEO as the "integrator" of the TMT (Buyl et al., 2011: 155) and the "guardian of the interactions among TMT members" (Cannella \& Holcomb, 2005: 223), we expect CEO characteristics to play a pivotal role in determining the performance effects of knowledge-based TMT faultlines. Indeed, leadership scholars have long stressed the central role of team leaders in promoting knowledge integration in diverse teams (Mesmer-Magnus \& DeChurch, 2009) and unpacking team diversity potential (Dionne, Sayama, Hao, \& Bush, 2010; Friedrich, Vessey, Schuelke, Ruark, \& Mumford, 2009; Klein, Ziegert, Knight, \& Xiao, 2006). To capture the integrative role of the CEO and develop our framework, we draw on the notion of crosscutting attributes and their importance in team diversity research.

Crosscutting is defined as "a decategorization strategy" that reduces the us versus them attitude in teams with strong subgroups, and promotes cross-subgroup integration and interaction (Rico, Sanchez-Manzanares, Mirko, \& Lau, 2012: 409). Such decategorization is achieved when at least one member of the team possesses characteristics that enable him or her 
to promote team collaboration and integration (Hornsey \& Hogg, 2000). This team member will act as the "crisscrossing" actor to establish a common ground of inter-subgroup communication and information exchange (Mäs et al., 2013: 720). The crisscrossing actor is therefore likely to enhance the performance of the team, as he or she will be able to act as a bridge-builder between the diverse information and expertise residing in knowledge subgroups (Carton \& Cummings, 2012).

Recently, scholars have argued that the most effective crisscrossing actors, or integrators, are those who hold powerful positions in the team - such as the leaders of the group (Gratton et al., 2007; Thatcher \& Patel, 2012). In a recent study, for example, Crawford and LePine (2013: 40) stress that "teams that differentiate into subgroups will need team members to adopt integrating roles in order to be effective". Such team members should be located "in enviable positions of power" that allow them to impact team processes and foster integration (Crawford \& LePine, 2013: 39). Building on this conception, we propose that crosscutting attributes of the CEO, as the central and most powerful leader of the TMT, will exert a key influence in reducing the fragmentation disadvantages of knowledge-based TMT faultlines and promote informational benefits and high performance.

To identify the critical CEO characteristics, we draw on the work of Crawford and LePine (2013), and suggest that effective integrators in teams with knowledge subgroups are those who: (a) can promote intra-team mutual identification, (b) possess the required variety of expertise to understand and synthesize the diverse knowledge residing in the team, and (c) have experienced common socialization processes with other team members through long term interaction. This corresponds with three dimensions of the CEO-TMT interface: (a) the relational CEO-TMT interface defined as the similarity between the CEO and the TMT in relational socio-demographic attributes; (b) the informational CEO-TMT interface defined as the variety of CEO career background; and (c) the socialization CEO-TMT interface defined as the team experience that the CEO shares with other TMT members. These dimensions of the 
CEO-TMT interface are expected to reduce the costs and enhance the informational and performance benefits of knowledge-based TMT faultlines.

$* * * * * * * * * * * * * * * * * * * * * * * * * * * * * * * *$

INSERT FIGURE 1 ABOUT HERE

$* * * * * * * * * * * * * * * * * * * * * * * * * * * * * * * *$

2.3.1. CEO-TMT socio-demographic similarity. Research on relational demography underscores the impact of externally observable socio-demographic characteristics on team dynamics and performance (e.g., Tsui, Egan, \& O'Reilly, 1992). While socio-demographic differences are associated with stereotyping and infrequent cooperation, similarity in relational socio-demographic attributes promotes mutual identification, interpersonal attraction, and ease of communication (Chattopadhyay, Tluchowska, \& George, 2004). In this study, we propose that CEO-TMT socio-demographic similarity will positively affect the performance implications of knowledge-based TMT subgroups. This claim pertains to the following reasons.

First, socio-demographic similarity between the leader of the team and subgroup members enables the former to reduce knowledge fragmentation and promote team cohesion and integration (Hoever, van Knippenberg, van Ginkel, \& Barkema, 2012). Research has shown that teams with members that are similar in demographic attributes are those that exhibit higher levels of unique information sharing and knowledge integration (Mesmer-Magnus \& DeChurch, 2009). A leader who shares common socio-demographic characteristics with other team members is better equipped to act as a bridge-builder by promoting effective elaboration of the team's task-relevant information (Mitchell et al., 2015; Rico et al., 2012). This bridgebuilding capacity is particularly important for CEOs, whose role is to integrate the diverse knowledge of the TMT (Buyl et al., 2011), and utilize this knowledge to shape decisions that positively impact firm outcomes (Cannella \& Holcomb, 2005). As demographic similarity breeds information exchange and integration (Turner, 1987), and as information exchange and integration are vital for the effective management of teams with knowledge-based faultlines 
(Carton \& Cummings, 2012), we expect CEO-TMT demographic resemblance to positively influence the performance implications of knowledge-based TMT subgroups.

Second, CEO-TMT similarity is likely to encourage TMT members to identify with the executive team's leader (Yoshida, Sendjaya, Hirst, \& Cooper, 2014), and thus establish intrateam identification (Wang \& Rode, 2010). According to the social identity theory of leadership (Hogg, 2001), demographic similarity acts as a key determinant of a leader's ability to generate a shared group identification (Mitchell et al., 2015; Waismel-Manor, Tziner, Berger, \& Dikstein, 2010), reduce the us versus them attitude between intra-team subgroups (Hirst, van Dick, \& van Knippenberg, 2009), and promote the development of shared mental models among team members (Mathieu, Heffner, Goodwin, Salas, \& Cannon-Bowers, 2000). When similarity between the leader and the rest of the team is high, team members are less susceptible to interpersonal stereotyping (Mitchell et al., 2015), as they emphasize their similarities to the team's leader rather than their differences with other members (Hirst et al., 2009). This leaderteam identification promotes cross-subgroup integration, which helps the leader to unlock the team's diverse knowledge potential (Hoever et al., 2012), and thus positively influence the performance impact of knowledge-based faultlines.

Hypothesis 1. CEO-TMT socio-demographic similarity has a positive moderating effect on the relationship between knowledge-based TMT faultlines and firm performance.

2.3.2. CEO experience variety. A recurrent theme in strategic leadership research relates to the impact of executives' past experience on strategic decision making and performance (Carpenter, Geletkanycz \& Sanders, 2004; Finkelstein et al., 2009). In a recent study, Crossland, Zyung, Hiller and Hambrick (2014) developed the notion of CEO experience variety, referring to the degree to which the leader of the executive group has acquired career experience from various areas of expertise and institutional settings. In this study, we suggest that CEO experience variety in terms of functional and international experience will have a positive 
moderating effect on the relationship between knowledge-based faultlines and firm performance. Our argument is supported by the following reasoning.

First, variety of career experience enhances the CEO's ability to reduce unproductive knowledge fragmentation in the TMT (Hambrick, 1995). As Cooper et al. (2014: 647) argued, individuals with variety of experience from different domains can act as bridge-builders between subgroups as they "demonstrate weaker subgroup identification." While CEOs who specialize in one area of expertise are inclined to favor the opinion of the subgroup that is similar to their own specialization (Meyer et al., 2015), CEOs with diverse career backgrounds are less likely to develop a preferential attachment to one particular subgroup - as they identify with multiple experiential backgrounds simultaneously (Bunderson, 2003). The greater ability of CEOs with a variety of functional and international experience to identify with multiple knowledge-based subgroups will reduce fragmentation tendencies in the TMT, promoting cross-subgroup knowledge integration and high performance.

Second, variety of functional and international experience provides executives with a versatile set of skills that make them more capable of processing a broader spectrum of information (Bunderson, 2003; Dragoni et al., 2014). Even though CEOs with variety of experiences typically possess less in-depth functional and country specific knowledge (Buyl et al., 2011; Georgakakis, Dauth \& Ruigrok, 2016), they are likely to have overlapping experience with members of different knowledge subgroups. This enables them to retrieve the dispersed pieces of knowledge that reside in the TMT, and synthesize this knowledge to promote innovation, learning, and high performance (Crossland et al., 2014; Karaevli \& Hall, 2006).

Third, extant leadership research highlights the key role of team leaders in capitalizing on the diverse informational networks of subgroup members (Friedrich et al., 2009; Klein et al., 2006). To successfully enact this role, team leaders need to possess variety in their own networks, covering different functional domains and institutional settings (Uhl-Bien, Marion, $\&$ McKelvey, 2007). This enables them to engage in crosscutting behavior, and thus effectively 
act upon opportunities in the team's overall network (Balkundi \& Kilduff, 2006; Rodan \& Galunic, 2004). Accordingly, a CEO with experience from different functional areas and countries has the necessary leverage to obtain a strong network position within a TMT with knowledge-based faultlines in functional and international experience. Such superior brokering capacities of CEOs will produce more effective use of TMT members' access to information and knowledge sharing (Carmeli, Gelbard, \& Reiter-Palmon, 2013), leading to high firm performance (Rodan \& Galunic, 2004). As Cohen and Levinthal (1990: 134) stressed, when the diverse networks of a team are integrated, “individuals' awareness of others' capabilities and knowledge will be strengthened," resulting in positive organizational outcomes.

Hypothesis 2. CEO career experience variety has a positive moderating effect on the relationship between knowledge-based TMT faultlines and firm performance.

2.3.3. CEO-TMT shared experience. Research on organizational behavior has underscored the impact of shared experience on team functioning and performance (Carroll \& Harrison, 1998; Harrison, Price, Gavin, \& Florey 2002; Mathieu et al., 2000). In the area of faultlines, scholars have posed shared team tenure as a crosscutting factor that increases intersubgroup socialization and integration (Mäs et al., 2013). We draw on this literature to suggest that CEO-TMT shared experience plays a key role in affecting the performance implications of knowledge-based faultlines.

First, research shows that overlapping team tenure allows members of a team to "develop a shared conceptualization of "who knows what'" in the group (Brandon \& Hollingshead, 2004: 633), and allocate tasks to those who possess the required expertise (Dai, Roundy, Chok, Ding, \& Byun, 2016). According to the resource-allocation model, effective team leaders are those who are aware of the information and skills that reside in the group, and can allocate resources in a way to enhance overall team performance (Kanfer, Ackerman, Murtha, Dugdale \& Nelson, 1994). A CEO who shares common socialization experience with 
other senior executives has an in-depth understanding of the knowledge residing in different TMT subgroups. This allows the CEO to activate the informational advantages of knowledgebased TMT faultlines by allocating tasks and responsibilities to the subgroups that possess the required specialization. Such effective task allocation allows the TMT to successfully deal with managerial complexity, resulting in enhanced firm-level financial outcomes.

Second, leadership studies have distinguished between vertical and shared leadership (e.g., Dionne et al., 2010; Pearce \& Sims, 2002). According to Ensley, Hmieleski, and Pearce (2006: 220) "vertical leadership is dependent upon the wisdom of an individual leader, whereas shared leadership draws from the knowledge of a collective.” Pearce, Conger, and Locke (2007) suggested that leaders who are able to move from a vertical- to a shared-leadership orientation are those who can mostly benefit from the diversity of skills and knowledge in the group. In a recent study, Hoch (2013) found that an antecedent of shared leadership is the degree of interpersonal trust (i.e., perceived integrity and trustworthiness) between the leader and other team members. CEOs who have overlapping experience with other top managers are more likely to develop mutually supportive social relationships of trust (Taylor \& Greve, 2006) that facilitate shared leadership between TMT knowledge subgroups and promote knowledge integration (Kunze, de Jong, \& Bruch, 2016). This will help the executive group to effectively utilize diversity (Dionne et al., 2010), promote quality of strategic decisions (Li \& Hambrick, 2005), and thereby realize desirable firm-level financial outcomes (Cooper et al., 2014).

Third, the fragmentation costs of knowledge-based faultlines are likely to be reduced over time, as team members acquire common socialization experiences with the team's leader (Balkundi \& Harrison, 2006). According to Taylor and Greve (2006: 728), teams with members who have worked for a long time in the same group tend to establish efficient communication patterns and can therefore "more easily utilize member diversity." In a recent study, Buyl et al. (2011: 157) found that overlapping team tenure between the CEO and other executives allows the former to "bridge semantic gaps" of information in the TMT, thereby enhancing integration 
among members with diverse expertise. In addition, Mathieu et al. (2000: 273) argued that overlapping experience allows team members to establish common "task-based mental models", and thus promote elaboration of diverse information and high team performance. Building on these arguments, we assume that CEO-TMT shared experience will have a positive impact on the relationship between knowledge-based TMT faultlines and firm performance.

Hypothesis 3. CEO-TMT shared experience has a positive moderating effect on the relationship between knowledge-based TMT faultlines and firm performance.

\section{Methods}

\subsection{Sample and data collection}

Our sample consists of large stock-listed international firms headquartered in four European countries (Germany, the Netherlands, Switzerland, and the United Kingdom) over the period 2005-2009. Focusing on this time period allows us to account for years before and after the financial crisis which started between 2005 and 2009. Indeed, recent research evidence shows that the effects of leaders on teams with faultlines are significantly influenced by whether the firm is facing an organizational crisis (Meyer et al., 2015). Having years before and after the financial crisis allows us to control for crisis-related effects that may impact our results ${ }^{1}$. To select our sample, we first ranked all listed firms in the four countries based on market capitalization, and the largest 100 from each country were included given that they fulfilled the following conditions: (a) they were classified as large firms based on the European Commission's definition (i.e., they had at least 250 employees and at least $€ 50$ million annual revenues), (b) they were not acquired, delisted, or ceased to operate during 2005-2009, (c) their ratio of foreign sales to total sales was greater than 0 (i.e., firms without international sales were excluded), (d) they were not consolidated subsidiaries of another (larger) firm, and (e) their

\footnotetext{
${ }^{1}$ As a robustness check, we re-ran our analysis with firm performance (ROA) adjusted to the average of each year. The yearadjusted analyses produce similar results to those presented in Table 2 - supporting the robustness of our findings. The results of this supplementary analysis are available upon request from the authors.
} 
TMTs consisted of at least four members ${ }^{2}$. By applying these criteria, we ensured that firms in our sample were comparable in terms of firm size and internationalization, were active over the period examined, were autonomous entities, and had the minimum TMT size that allows for the presence of subgroups (Bezrukova et al., 2009; Hutzschenreuter \& Horstkotte, 2013).

This filtering resulted in a dataset of 248 large international firms. Due to data unavailability, a number of cases with missing values were dropped - leaving a final sample of 97 firms and 347 firm-year combinations. This data completion rate is similar to other studies that use information on CEOs' and top managers' entire career profiles (e.g., Crossland et al., 2014). We ran t-tests to examine whether there are significant differences between the final sample and the cases with missing values in terms of firm performance (return on assets) and firm internationalization (ratio of foreign sales divided by total sales). Results show that the sample means are not significantly different, suggesting that our final sample is a reasonable representation of the target population.

Data about CEOs and other executives were collected from annual reports, corporate websites, and archival sources (e.g., LexisNexis, Who's Who in Europe). Firm- and industrylevel data were gathered from the ThomsonOne Banker database. The four European countries were selected for the following reasons. First, the stock exchanges in the four countries are among the leading stock exchanges in Europe in terms of domestic market capitalization (World Federation of Exchanges, 2013). These reputable stock exchanges act as homes for many international firms (Ghemawat, 2013), which attract a wide pool of CEOs and other executives with diverse international experiences and functional backgrounds. This offers a suitable setting for assessing the performance implications of knowledge-based TMT faultlines. Second, the four European countries differ significantly in terms of country-level CEO managerial

\footnotetext{
${ }^{2}$ In line with prior studies, we applied a minimum team size of four members in the calculation of faultlines, so that all teams have the potential to form subgroups (Bezrukova et al., 2009; Hutzschenreuter \& Horstkotte, 2013). Importantly, this approach does not restrict the faultlines calculation to cases of equally-sized subgroups only, but also includes non-equally sized subgroup constellations (Meyer \& Glenz, 2013; Thatcher et al., 2003). In addition, we re-ran our analysis with three-member teams included. Results do not substantially differ from those presented in Table 2 and are available upon request from the authors.
} 
discretion (Crossland \& Hambrick, 2011). Controlling for the level of CEO managerial discretion in each country is important (Crossland \& Hambrick, 2011), as it allows us to take into consideration the degree to which the CEO has the latitude to act as the leader of the group and affect TMT composition and outcomes (Wangrow, Schepker \& Barker, 2015). Adopting a multi-country sample with variety in CEO discretion therefore enables us to take into account cross-country differences in CEOs' latitude of action - something that prior research has regarded as key to enhance the generalizability of the upper echelons perspective beyond the frequently assessed US context (Crossland \& Hambrick, 2011; Hambrick, 2007).

\subsection{Dependent variable: Firm performance.}

This variable was measured as the two-year average return on assets (ROA) after each respective observation (Chung \& Luo, 2013; Shen \& Cannella, 2002). The time-lagged structure allows us to reduce potential bias of single year outliers in ROA, and account for the implied causality in the studied relationship. We focus on ROA as it has been regarded as the most "well-understood and widely used" accounting measure of financial performance in TMT research (Shen \& Cannella, 2002: 723). As we focus on the effects of top managers on firm outcomes, we did not use any market valuation performance measures since such measures are “often subject to forces beyond management control” (Chung \& Luo, 2013: 345).

\subsection{Independent variable: Knowledge-based TMT faultines.}

To measure knowledge-based TMT faultlines, we first coded the dominant functional and country experience of all TMT members including the $\mathrm{CEO}^{3}$. Dominant functional

\footnotetext{
${ }^{3}$ Recent research on the role of the leader in affecting the performance effects of faultlines has argued that all members (including team leaders) should be considered in the formation of subgroups (e.g., Meyer et al., 2015). In addition, most of studies on the CEO-TMT interface include the CEO as a group member when measuring salient team-level constructs - such as behavioral integration (Ling et al., 2008; Friedman et al., 2016), TMT trust (Carmeli et al., 2012) and TMT potency (Carmeli et al., 2011). Our results in Table 2 are therefore based on a team-level faultlines calculation that includes the CEO and other TMT members. To check the robustness of our results, we ran additional analysis with the CEO excluded from the TMT faultlines calculation. Results of this analysis show that our main effect and interaction effects receive statistical support supporting the robustness of our findings. Results of the supplementary analyses are available upon request from the authors.
} 
background and international experience were coded as the functional category and country in which an executive had mainly worked throughout his or her career. The functional categories used were: engineering; production and operations; accounting and finance; R\&D; marketing and sales; management and business administration; law; personnel and labor relations; strategy development; other. This functional categorization is based on the studies of Cannella et al. (2008) and Michel and Hambrick, (1992), which have been widely used in the area of TMT and board diversity (e.g., Tuggle, Schnatterly \& Johnson, 2010; Heyden, Oehmichen, Nichting \& Volberda, 2015; Oehmichen, Heyden, Georgakakis \& Volberda, 2017).

To identify the dominant function and country of experience, we considered the years in which an executive had worked in each functional category and country from the beginning of his or her career until the year of observation. The functional category and country in which the individual had spent most of his or her career (in years) was coded as dominant. In cases we were unable to identify the year of an individual's career start, we took the year of graduation of the highest academic degree - albeit not counting for Master of Business Administration (MBA) and Executive Education degrees which are typically pursued at a later career stage. In rare cases where the executive had worked the same number of years in two categories, we coded the most recently acquired as dominant background. Also, in cases where the number of years for all experience categories could not be ascertained, but enough information was provided about the executive's career profile, we coded dominant background the category that was most frequently mentioned in the executive's curriculum vitae. This allowed to maximize data completion in terms of dominant functional and international background of executives.

After coding the variables, we calculated the strength of TMT knowledge-based faultlines using the Fau formula of Thatcher, Jehn and Zanutto (2003), expressed as:

$$
\operatorname{Fau}_{g}=\left(\frac{\sum_{j=1}^{P} \sum_{k=1}^{2} n_{k}^{g}\left(\bar{x}_{\bullet j k}-\bar{x}_{\bullet \cdot \cdot \cdot)^{2}}\right.}{\sum_{j=1}^{P} \sum_{k=1}^{2} \sum_{i=1}^{n_{k}^{g}}\left(x_{i j k}-\bar{x}_{\bullet \cdot \cdot \cdot)^{2}}\right.}\right) \quad g=1,2, \ldots S,
$$


where ${ }^{x_{i j k}}$ represents the value of the $j^{\text {th }}$ characteristics of each individual $i$ in the knowledge subgroup $k, \bar{x}_{\bullet j \bullet}$ denotes the team's mean in the characteristic $j, \bar{x}_{\bullet j k}$ represents the mean of the attribute $j$ in the $k^{\text {th }}$ knowledge subgroup, and $n_{k}^{g}$ is the total number of members in the $k^{\text {th }}$ knowledge subgroup as of split g. Faultlines strength was subsequently measured as the highest value of $\mathrm{Fau}_{\mathrm{g}}$ based on all potential splits $\mathrm{g}=1,2, \ldots \mathrm{S}$. To calculate the Faug index, we used the statistical program R and the asw.cluster package (Meyer \& Glenz, 2013).

\subsection{Moderator variables}

3.4.1. CEO-TMT socio-demographic similarity. This variable is a composite of a CEO's similarity to the rest of the TMT in terms of two externally observable socio-demographic attributes: age and gender ${ }^{4}$. Compared to demographic differences in experiences and education, these attributes reflect the underlying social-identities of individual executives (Crucke \& Knockaert, 2016; Milliken \& Martins, 1996; van Knippenberg et al., 2004; Veltrop, Hermes, Postma \& de Haan, 2015) and have been used in the extant literature as predictors of similarity attraction inclinations (Bezrukova et al., 2009). Since Hypothesis 1 assumes that CEO-TMT similarity triggers social-identification processes between the CEO and the TMT, focusing on these social attributes instead of informational characteristics (e.g., level of education) fits better to the purpose of the study.

As age is a continuous variable, age similarity between the CEO and the TMT was calculated using the distance formula $\sqrt{\sum(X i-X j)^{2} /(n-1)}$ (Westphal \& Zajac, 1995). In this formula, $\mathrm{X}_{\mathrm{i}}$ represents the age of the CEO $\mathrm{i}, \mathrm{X}_{\mathrm{j}}$ represents the age of each non-CEO executive $\mathrm{j}$, and $\mathrm{n}$ is the number of TMT members. To turn this into an age similarity measure, we reversed

\footnotetext{
${ }^{4}$ We ran supplementary analysis with nationality as an additional component of the CEO-TMT similarity composite. In line with prior studies, executives' nationality was coded based on the information provided in firms' annual reports and corporate websites (e.g., Greve, Biemann, \& Ruigrok, 2015). Results of the supplementary analysis are similar and in the same direction as those presented in Table 2 . Since nationality similarity was highly (negatively) correlated with CEO international experience variety $(\mathrm{R}=-0.32)$, we decided to not include it in the overall CEO-TMT similarity measure in order to avoid potential confounding effects. Results of the supplementary analyses are available upon request from the authors.
} 
the variable so that higher scores indicate higher similarity. Further, CEO-TMT gender similarity was measured using a modified version of Blau's (1977) formula expressed as $\mathrm{Pi}^{2}$, where $\mathrm{P}$ is the proportion of TMT members that share the same gender category $i$ with the CEO. To calculate the overall CEO-TMT similarity measure, we rescaled age similarity to take values between 0 and 1, and then aggregated the two components in a composite variable.

3.4.2. CEO experience variety. Similar to the study of Crossland et al. (2014), CEO experience variety was measured based on the functional and country-level career experience of the CEO. First, functional experience variety was measured as the number of functional categories in which the CEO had worked divided by his/her career length. Second, international experience variety was calculated as the number of countries in which the CEO had gained career experience divided by his/her career length. To calculate the CEO experience variety we aggregated the two components into an overall CEO experience variety measure.

3.4.3. CEO-TMT shared team experience $(\log )$. This variable was measured using the procedure suggested by Carroll and Harrison (1998), which averages pairwise overlap of team tenure (TLAP) for all possible pairs in the team. Carroll \& Harrison's (1998) TLAP formula is expressed as: $1 / N \sum_{i \neq j} \min \left(\mathrm{u}_{\mathrm{i}}, \mathrm{u}_{\mathrm{j}}\right)$, where u represents the TMT tenure (in years) of each individual $i$. Since we are interested in the tenure overlap of the CEO with other TMT members, we measured the average pairwise tenure overlap between the CEO and other senior executives. To account for the diminishing effect of team members' interaction over time we transformed this variable by taking the natural logarithm (Buyl et al., 2011).

\subsection{Control variables}


Similar to prior studies, we control for past firm performance (Cannella et al., 2008), measured as the three-year average ROA up to, and including, the year of observation (Shen \& Cannella, 2002). Research has stressed that TMT size and firm size are associated with TMT composition and outcomes (Carpenter et al., 2004). Thus, team size, measured as the logarithm of the exact number of TMT members, and firm size, measured as the logarithm of total employees, were controlled. As education is an indicator of generic skills, we control for $C E O$ level of education and TMT average level of education. Educational level was coded as 1 for no academic degree, 2 for a Bachelor's degree, 3 for a Master's degree, 4 for an MBA degree, and 5 for a PhD degree or equivalent (Pegels, Song \& Yang, 2000).

Since our variable of CEO-TMT shared experience is likely to be augmented when the CEO's tenure is higher, we controlled for CEO's team tenure. Similar to the CEO-TMT tenure overlap, we transformed this variable using the natural logarithm. To ensure that the effect of knowledge-based TMT faultlines is distinct from the possible co-existence of other types of subgroups, we controlled for identity-based TMT faultlines in three externally observable attributes that reflect the social-identities of TMT members - age, gender, and nationality (Thatcher \& Patel, 2012). Similar to knowledge-based faultlines, identity-based faultlines were measured using the formula developed by Thatcher et al. (2003). Further, to measure industry munificence we first calculated the regression coefficient of time on the annual average sales in the two-digit industry (based on Standard Industry Classification) of a firm over a period of five years (i.e., two before to two after each year of observation). Then, we divided the resulting value by the average sales of the respective five-year period (Dess \& Beard, 1984). Finally, to control for country-level CEO discretion, we used the scores provided in the study of Crossland and Hambrick (2011: 806). The UK had the highest CEO discretion score of 6.0, followed by the Netherlands and Switzerland with 5.2 and 5.0 respectively, and Germany with 4.1.

\section{Results}


As our analysis is based on a longitudinal dataset, we employed a generalized least squares (GLS) regression. In panel data analysis, particular attention should be paid to the choice between fixed- and random-effects approaches. When time invariant variables are included, a random-effects approach is more appropriate (Greene, 2003). As our analysis includes time-invariant variables (i.e., CEO country-level discretion) we adopted a random effects approach. Table 1 presents means, standard deviations, and correlations. Table 2 provides the results of the GLS models. To observe incremental changes in variance explained across different stages of the analysis, we first entered control variables in a baseline model, and then added our independent variable and interaction effects in subsequent models. To check for multicollinearity, we ran variance inflation factor (VIF) tests in a separate OLS regression (Cannella et al., 2008). The highest VIF score was 2.03, with an average of 1.52. This implies that multicollinearity is not an issue in our analysis, as both scores are below the generally accepted VIF threshold (see e.g., Cohen, Cohen, West \& Aiken, 2003).

Our analysis distinguishes between knowledge-based and identity-based faultlines (see Table 2). Our results show that these two types of TMT faultlines have different effects on firm performance. Namely, knowledge-based TMT faultlines have a negative and significant effect, while identity-based TMT faultlines do not exhibit a significant impact. This implies that in the context of TMTs of large international firms, knowledge-based subgroups are more relevant to explain firm performance; and on average have detrimental effects. However, our results also show that these negative ceteris-paribus effects of knowledge-based faultlines are significantly altered by the attributes and background of the group's leader (see Figures 2 to 4$)^{5}$.

Hypothesis 1 predicts that CEO-TMT socio-demographic similarity has a positive moderating effect on the relationship between knowledge-based TMT faultlines and firm performance. Our results substantiate this hypothesis (see Table 2), showing that the effects of

\footnotetext{
${ }^{5}$ Following the suggestions of Dawson (2014), all independent, moderator, and control variables were z-standardized in order to plot interaction findings in Figures 2 to 4.
} 
knowledge subgroups at the TMT level vary with the relational crosscutting attributes of the CEO (see Figure 2). Further, hypothesis 2 predicts a positive moderating effect of CEO career experience variety ${ }^{6}$. Our results support this hypothesis (see Table 2). This finding implies that CEOs with diverse career experience are better equipped to reduce the negative effects of knowledge-based subgroups (see Figure 3). Finally, hypothesis 3, which predicts that CEOTMT shared team experience has a positive moderating impact on the relationship between TMT faultlines and firm performance, is corroborated. This finding implies that overlapping team tenure between the CEO and other TMT members helps to overcome the negative effects of knowledge-based factions at the group level (see Figure 4).

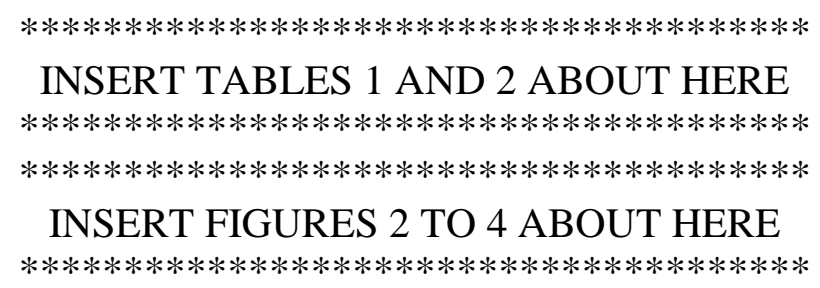

\section{Discussion}

Scholarly inquiry on how TMT faultlines impact organizations has gained momentum. Yet, extant research on the performance implications of knowledge-based TMT subgroups has been largely inconclusive. By building an important bridge between strategic leadership and team diversity research, this study highlights the CEO-TMT interface as a key mechanism that influences the performance implications of knowledge-based TMT subgroups. Our results reveal that the disadvantageous ceteris-paribus effects of knowledge-based TMT faultlines on firm performance are likely to be overcome when the team's leader (i.e., the CEO): (a) sociodemographically resembles other top managers, (b) possesses career experience variety, and (c) has overlapping team tenure with other TMT members (see Figures 2 to 4 ).

\footnotetext{
${ }^{6}$ As knowledge-based TMT faultlines and CEO career variety exhibit a significant correlation at $\mathrm{R}=-0.13$ (see Table 1), we ran supplementary analysis controlling for the squared effects of the main predictor and the CEO career variety moderator (Cortina, 1993; Edwards, 2008). Results show that our findings remain significant when squared terms in these two variables are controlled. This implies that our interaction results are not unduly influenced by the correlation between the main predictor and the moderator variable. We would like to thank an anonymous reviewer for this suggestion. Results of the supplementary analysis are available upon request from the authors.
} 
First, as Figure 2 shows, CEOs who are similar to other executives in externally visible socio-demographic characteristics are more likely to raise the performance of TMTs with strong knowledge-based faultlines. At the same time, knowledge-based faultlines have a strong negative effect on firm performance when CEO-TMT socio-demographic similarity is low. This finding supports the notion of crosscutting diversity (Rico et al., 2012), which suggests that similarity between the leader of the group and other team members in relational sociodemographic traits allows the former to act as a crisscrossing actor (Mäs et al., 2013), and suppress the negative effects of TMT subgroup formation (Crawford \& LePine, 2013). The inherent tendency of individuals to like, trust, and interact with those who demographically resemble themselves (Tajfel, 1978) enables socio-demographically entrenched CEOs to act as bridge-builders, and reduce the disadvantageous impact of knowledge schisms in the TMT.

This finding lends support to the notion that informational diversity is more likely to translate into desirable performance outcomes when there are redundancies among team members in externally-observable relational attributes (Strasser \& Titus, 1985). In a recent meta-analysis, Mesmer-Magnus and DeChurch (2009) demonstrated that knowledge-related teams are more likely to engage in unique information sharing and knowledge integration under conditions of high team homogeneity. Our results expand this line of argumentation, by showing that team leaders (i.e., CEOs) who resemble other team members are better equipped to overcome the knowledge fragmentation costs of faultlines - and promote higher firm performance in the presence of strong knowledge-based TMT subgroups. To this end, our work underscores the importance of incorporating relational demography in studies at the intersection of upper echelons, team diversity and leadership research (Chang \& Johnson, 2010; Finkelstein et al., 2009; Hambrick, 2007).

Second, our results demonstrate that TMTs with strong knowledge-based faultlines are likely to enhance their performance when they are led by a CEO who possesses a diverse career background. At the same time, when the CEO lacks diverse experience, TMT knowledge 
subgroups have a strong negative impact on firm performance (see Figure 3). Variety of experience and networks from different functional areas and institutional environments enables team leaders to reduce the disadvantageous aspects of knowledge subgroups. Indeed, this finding is in congruence with studies which argue that team leaders with a diverse career background can effectively understand the variety of information, networks, and expertise residing in the team (Crossland et al., 2014) and allocate resources in a way to reduce the fragmentation costs of subgroup formation (Kanfer et al., 1994). In this regard, our study helps to improve our understanding of how CEOs with diverse career backgrounds affect the performance implications of TMT composition and subgroups formation (Crossland et al., 2014).

Third, consistent with the team diversity literature (Harrison et al., 2002), our study provides evidence that the effects of TMT knowledge-based faultlines depend on the length of time the individual leader has worked with other members of the team. As shown in Figure 4, the relationship between knowledge-based TMT subgroups and firm performance is positive when CEO-TMT shared experience is high, and negative when CEO-TMT shared experience is low. Overlapping tenure between the CEO and the TMT may allow the former to become familiar with the diverse knowledge of intra-team subgroups, and utilize this knowledge to make performance-enhancing decisions (Gratton et al., 2007). In this regard, our findings indicate that the pursuit of TMT diversity, and particularly the creation of complex TMT constellations characterized by knowledge-based faultlines, can be considered as a long term strategy that may produce desirable performance outcomes after some period of time, rather than in the short-run (Harrison et al., 2002; Taylor \& Greve, 2006).

A wider implication of this finding about the positive moderating effect of CEO-TMT tenure overlap (see Figure 4) derives from the notion of shared leadership in long tenured teams (D'Innocenzo, Mathieu, \& Kukenberger, 2014). Studies have shown that team longevity is associated with the development of converged mindsets (Dai et al., 2016) and collective 
leadership processes (Fischer, Dietz, \& Antonakis, in press; Hoch, 2013; Kunze et al., 2016) that allow the group's leader to promote collective decision making behavior. In teams with strong knowledge subgroups, the development of task-based mental models (Mathieu et al., 2000) and leadership processes are of fundamental importance, as they act as a common platform of communication between subgroups, and help the entire team to enhance its collective information processing potential and performance (Gratton et al., 2007; Kearney \& Gebert, 2009). Future work can expand our research model by examining how leader-member shared experience promotes intermediate leadership processes (e.g., shared or collective leadership) that, in turn, affect the performance implications of knowledge-based faultlines. This will help to further appreciate the "intersection of faultlines and leadership" (Thatcher \& Patel, 2012: 1000) and improve our understanding of the leader's role in influencing the performance effects of subgroup formation.

\subsection{Theoretical contributions}

Our study offers several theoretical contributions. Despite Jackson's (1992) and Hambrick's (1994) early suggestions to investigate the impact of CEO attributes on the relationship between TMT composition and firm outcomes, research on the CEO-TMT interface has remained scarce (Simsek et al., 2015). To the best of our knowledge, this is the first effort to examine how different CEO-TMT characteristics help in managing the presence of TMT knowledge subgroups. By integrating the notion of the CEO-TMT interface in the faultlines literature, our study responds to the calls of upper echelons scholars to investigate the CEO's role in exacerbating or neutralizing both advantageous and disadvantageous effects of different forms of TMT diversity (Carpenter et al., 2004). Our findings confirm that a closer scrutiny of the interface between the CEO and the TMT can help to enhance the explanatory power of upper echelons theory (Cannella \& Holcomb, 2005; Hambrick, 1994), and improve 
our understanding of how CEOs and other executives interdependently and interactively impact organizations (Klimoski \& Koles, 2001).

Indeed, scholars have argued that a key reason for the relatively slow progress in upper echelons research is that prior literature has paid insufficient attention to the team-level mechanisms that impact the effects of TMT configuration (Finkelstein et al., 2009). Our work captures three dimensions of the CEO-TMT interface (i.e., relational, informational, and socialization) as team-level mechanisms that affect the performance implications of knowledge subgroups. Our findings jointly imply that modeling the CEO-TMT interaction can help to complement, and improve our current understanding of the effects of CEO characteristics and TMT composition on firm-level outcomes (Hambrick, 2007: 337). Future work should continue to shed light on the various micro-level CEO-TMT processes, such as leader-member exchange (Lin \& Rababah, 2014), shared mental models (Mathieu et al., 2000), and shared authentic leadership (Hmieleski et al., 2012) that moderate the performance effects of TMT configuration. We believe that taking a closer look at the CEO-TMT micro-level processes can be a fruitful path to unlock the upper echelons black-box (Lawrence, 1997), and hence move "toward a more realistic view" on how CEOs and other executives interact to impact organizations (Cannella \& Monroe, 1997: 213).

Apart from its contribution to the upper echelons literature, our work has implications that are relevant for the broader audience of team research. For TMTs, firm-level financial performance can be considered as a valid indicator of team performance (Cooper et al., 2014; van Knippenberg et al., 2011). From this point of view, our results may be generalized to teams - beyond the TMT level - that face similar information processing and leadership demands. Studies, for example, have shown that several teams at other levels of the management hierarchy - such as middle management teams (Minbaeva, Pedersen, Björkman, Fey \& Park, 2014; Heyden, Fourne, Koene, Werkman \& Ansari, in press), or entrepreneurial new venture teams (Lim, Busenitz \& Chidambaram, 2012) - face increasing informational requirements and 
task complexity. Our research shows that under conditions of extensive informational demands, the role of the leader may be critical in reducing semantic gaps among intra-team knowledge subgroups -and therefore improve the information processing capacity and performance of the team. In this regard, our work underscores the importance of integrating the notion of leadership into the broad area of team research in order to appreciate how team composition triggers teamlevel performance outcomes.

Further, the study contributes to the faultlines theory by highlighting the key role of the leader in determining the effects of knowledge-based subgroups (for reviews, see: Carton \& Cummings, 2012; Thatcher \& Patel, 2012). Although we did not hypothesize a main effect of knowledge-based faultlines, our results show that - ceteris paribus - knowledge-based TMT subgroups within a context of extensive information processing demands (i.e., in large international firms) have detrimental performance effects. Indeed, the observed negative baseline effect of knowledge faultlines is in congruence with Lau and Murnighan's (1998) faultlines theory, which suggests that the split of the team into subgroups - even in work-related experiential characteristics - can elicit high levels of fragmentation, task conflict, and poor performance. Thus, we find that knowledge-based faultlines have detrimental effects when all other factors are treated as constant (Bezrukova et al., 2012). However, our findings also show that the detrimental ceteris paribus effects of TMT knowledge-based faultlines are counterbalanced when the leader of the TMT possesses the skills and crosscutting characteristics to act as an effective knowledge integrator (see Figures 2 to 4 ).

Indeed, the observed interaction effects at the leader-team level shed new light on the seemingly contradictory findings in the extant knowledge-based faultlines literature. They demonstrate that the performance impact of knowledge subgroups is inherently sensitive to the leadership context in which the team is embedded. In particular, our results show that team leaders need to possess characteristics that are embodied in the demand for knowledge integration across subgroups, otherwise they may struggle to avoid negative performance 
consequences in teams with strong knowledge faultlines. Overall, studies carried out in contexts where the leader of the group faces difficulties to promote knowledge integration - such as in cases of cross-cultural joint ventures (e.g., Li \& Hambrick, 2006) or in teams with diverse goals (e.g., van Knippenberg et al., 2011) - are likely to find a strong negative relationship between knowledge-based subgroups and performance (see Figures 2 to 4). On the other hand, studies performed in contexts where the group leader can effectively promote integration and information sharing (Bezrukova et al., 2009; Cooper et al., 2014) are likely to observe different performance effects in teams with strong knowledge subgroups. To this end, our results support the notion that - in order to resolve inconsistent findings on the effects of knowledge faultlines - research should pay attention to the leadership context (Thatcher \& Patel, 2012), and more specifically, to the interactional interface between the team's leader and subgroup members (Meyer et al., 2015).

\subsection{Managerial Implications}

Together with its theoretical relevance, our study offers practical implications. As organizations become increasingly complex, TMTs frequently rely on subgroups of knowledge specialization to accomplish key tasks and objectives (Guadalupe et al., 2014). Yet, our analysis shows that the development of knowledge-related factions in the executive team carry the risk of delivering suboptimal firm performance outcomes. There is a trade-off that organizations should consider between information and knowledge availability that can promote creativity and learning (Hoever et al., 2012), and a risk of knowledge fragmentation between subgroups that may lead to undesirable organizational effects (Bezrukova et al., 2012). To avoid fragmentation costs and low performance from the presence of strong knowledge-based subgroups, firms need to ensure that sufficient bridge-building capacity is in place at the leaderteam level to foster knowledge exchange and integration. 
Broadly speaking, our results show that knowledge-based TMT faultlines have a negative baseline effect on firm performance. In addition, our plots depict that even under conditions where the team leader has the characteristics to act as an effective integrator and crosscutting actor, teams with strong knowledge-based faultlines do not outperform those without knowledge-based subgroups (see Figures 2 to 4). From an applied viewpoint, this can be interpreted as a suggestion that firms should prevent knowledge-based subgroup formation when they compose their TMTs. This, however, would be an undesirable and unrealistic strategy for the following reasons. First, it would restrict firms in the selection of highly qualified candidates with diverse knowledge backgrounds - ready to take charge in key strategic leadership positions and deal with the high information processing demands facing large organizations. Second, as past research has shown, teams with informational subgroups perform higher under some contextual conditions (Cooper et al., 2014). From an applied viewpoint, the most viable strategy for firms would thus be to learn how to manage knowledgebased TMT faultlines - rather than preventing the development of knowledge-based subgroups (van Knippenberg et al., 2011).

Overall, our work suggests that when organizations compose their strategic leadership teams, they should take into consideration the underlying behavioral processes that are likely to emerge at the CEO-TMT interactional interface (Simsek et al., 2015). While the use of archival data does not allow us to directly measure the micro-level CEO-TMT interpersonal dynamics, our empirical results implicitly suggest that the positive as well as negative effects of knowledge-based TMT faultlines depend on the relational, informational, and socialization processes that characterize the CEO-TMT interaction. For instance, CEO-TMT similarity is likely to foster similarity attraction inclinations between the CEO and members of subgroups that promote relational integration (Michel \& Hambrick, 1992), leader-member identification (Yoshida et al., 2014), and thus desirable performance outcomes. In addition, CEO career variety and CEO-TMT shared experience are likely to promote processes of effective 
information exchange (Buyl et al., 2011) and cross-subgroup socialization (Mäs et al., 2013; Taylor \& Greve, 2006) that positively affect the performance of teams with strong knowledge subgroups. To avoid the disadvantageous aspects of knowledge-based faultlines, firms should therefore pay attention to the relational, informational and socialization 'fit' between the leader of the group and other team members and - perhaps most importantly - to the development of underlying processes through which this fit, or misfit, translates into performance effects.

Further, our results may imply that CEOs need time until they learn how to utilize the knowledge diversity that resides in TMTs with strong faultlines, and promote organizational effectiveness. As Figure 4 shows, the effects of knowledge-based faultlines on firm performance vary from negative to positive with the tenure overlap between the CEO and the TMT. This may mean that the length of time the leader of the group and other team members work together play an important role in allowing the CEO to learn about the knowledge and information residing in the TMT, and thus to positively influence the effects of knowledgebased TMT faultlines on firm performance. Based on this logic, we may argue that firms should provide leaders with time to learn and effectively manage teams with strong knowledge-based subgroups. In cases where firms cannot afford this learning period, they might benefit from giving a new CEO the mandate to compose the executive group with members who have worked with in the past, and can utilize their diverse knowledge in a way that enhances firm performance. However, our work does not directly measure the exact processes and factors that determine how quickly CEOs learn about the capabilities of their TMTs. Future work can use micro-level data on CEO-TMT learning processes to shed further light on this important topic.

\subsection{Limitations and Future Research}

The study is subject to some limitations that open promising research avenues. A key limitation is that - due to the archival nature of our data - we are unable to directly delve into the micro-level processes such as behavioral integration, information exchange, and shared 
leadership through which CEOs with crosscutting characteristics impact the performance effects of TMT faultlines. While such a micro-level approach is beyond the scope of the current study, we do encourage future work to use other research designs, such as multiple case studies, to delve into the leadership processes through which CEOs and TMTs interactively impact the performance implications of knowledge-based subgroups.

Further, we define and measure the notion of knowledge-based faultlines in terms of two informational attributes (i.e., functional and international experience), and therefore do not consider other experiential characteristics (e.g., educational background or team tenure) that may cause subgroup formation. We have argued that functional background and international experience are two types of knowledge directly linked to the global leadership and task demands facing TMTs in large international firms (Cannella et al., 2008; Carpenter et al., 2001; Dragoni et al., 2014). Future work, however, can go beyond these attributes and investigate how other types of informational TMT subgroups impact the performance of smaller firms or non-profit organizations. In addition, in this study we control for identity-based faultlines and observe non-significant effects on firm performance. These non-significant effects, however, may be due to the small representation of women in top tier managerial positions of large international firms. Further research should hence examine the performance effects of identity-based faultlines in other teams with higher representation of women to see whether the observed nonsignificant effect holds beyond the TMT context.

Relatedly, future research is required to shed light on the moderating effects of CEOTMT similarity in attributes additional to, or other than, age and gender. For example, future studies can consider how similarity between the team leader and group members in other externally observable socio-demographic characteristics impact the relationship between knowledge-based faultlines and firm performance. In a similar vein, future work can investigate how CEO-TMT similarity in deep-level personality traits impact the performance implications on knowledge-based TMT subgroups. Such a research effort will help us to gain a wider view 
on how relational demography and personality fit between the leader of the team and other team members influences the performance implications of TMT composition.

Another limitation of our study is that it focuses on the effects of diversity as faultlines, and thus, it only explains the impact of group leaders on the performance implications of diversity as separation - rather than as variety or disparity (Harrison \& Klein, 2007). As we have argued, we focus on faultlines since this form of diversity is associated with high levels of knowledge fragmentation - and an us versus them behavior - that call for crosscutting leaders who are able to promote integration between subgroups (Harrison \& Klein, 2007; Mäs et al., 2013). At the same time, studies have shown that teams with other forms of diversity also need to promote integration in order to realize high performance (see e.g., Buyl et al., 2011; Hornsey \& Hogg, 2000). Future research can use the categorization of different forms of diversity provided by Harrison and Klein (2007) (i.e., variety, separation and disparity) to examine the role of group leaders in promoting integration and performance benefits in heterogeneous teams. This can help us not only to unravel inconsistent findings in the extant team diversity literature, but also to fully grasp the importance of leadership in translating different forms of team composition into beneficial outcomes for organizations.

Further, we have focused on three CEO crosscutting characteristics that help to enhance the information processing and performance outcomes of TMT faultlines (i.e., CEO-TMT similarity; CEO experience variety; CEO-TMT tenure overlap). However, these may not be the only factors that affect the TMT faultlines-firm performance relationship. Recent studies, for example, provide evidence on how the leadership style of the group's leader impact the performance effects of team composition (e.g., Gratton et al., 2007). At the same time, other studies have highlighted the role of exogenous factors, such as industry dynamism or environmental complexity that affect the performance effects of TMT faultlines (Cooper et al., 2014). An interesting extension of our study would hence be to develop a multilevel framework that examines how the micro-level traits of the group's leader jointly with environmental factors 
impact the relationship between intra-team knowledge subgroups and performance. This will enable us not only to further contribute to the resolution of the inconsistent findings in the extant knowledge-based faultlines literature, but also to move toward a holistic view on the contingent nature of subgroup formation, and its effects.

Moreover, another interesting avenue for future research is to examine the intrasubgroup compositional factors that affect the performance implications of knowledge-based faultlines. Prior research has argued that - even when subgroups are strong - the effects of faultlines can be significantly influenced by who are the members of different subgroups, and how influential they are in decision making (Thatcher \& Patel, 2012). In a recent study, for example, Meyer et al. (2015) found that individual members who belong to the same subgroup as the team's leader exhibit higher levels of performance compared to those who belong to a different subgroup. In addition, faultline dynamics in the TMT may be different when one subgroup consists of powerful functional executives (i.e., CFO, COO), while the other subgroup comprise less influential TMT members (Menz, 2012). Future work should thus examine the effects of knowledge-based faultlines by considering the functions and influence of subgroup members, and how different intra-subgroup constellations affect team and firm outcomes.

Finally, this study is limited to the top tier of organizational leadership (i.e., to the top management team). As "leadership in organizations is an inherently multilevel phenomenon" (DeChurch, Hiller, Murase, Doty \& Salas, 2010: 1069; see also: Epitropaki, Kark, Mainemelis \& Lord, 2017), future work can go beyond the CEO-TMT level and consider how the leadermember interface at lower levels of the management hierarchy impact team and firm performance. Jacobs and McGee (2001), for example, differentiated levels of leadership based on the three-tiered organizational design. At the lower levels of management (i.e., line managers), leadership is mainly concerned with the supervision of tasks. At the middle levels (middle managers), leaders develop goals to meet specific business unit objectives. Finally, at the top level of leadership executives establish the vision and strategy of the organization. Based 
on this three-tier leadership view, Zaccaro and Klimoski (2001) suggest that even though leaders at different levels enact similar roles, such as direction setting and maintenance of capabilities, they do so through different leadership processes (see also: Hiller, DeChurch, Murase \& Doty, 2011). An interesting extension of our study would thus be to examine how the interface between the leader and knowledge subgroups impact team performance within and across hierarchical levels of an organization (Yammarino, Dionne, Chun, \& Dansereau, 2005).

In conclusion, our study takes a step toward a better understanding of how the CEO's characteristics moderate the performance effects of TMT subgroup formation. Our theory and empirical results may prompt further research to examine the conditions under which firms can benefit from the presence of knowledge subgroups - by appreciating the key role of the team's leader in this process. As firms become aware of the leadership factors that influence the performance effects of different forms of team composition, we can expect that workplace diversity will be increasingly translated into a valuable source of innovation, and economic prosperity, in the years to come.

\section{References}

Balkundi, P., \& Harrison, D. (2006). Ties, leaders, and time in teams: Strong inference about the effects of network structure on team viability and performance. Academy of Management Journal, 49, 49-68.

Balkundi, P., \& Kilduff, M. (2006). The ties that lead: A social network approach to leadership. The Leadership Quarterly, 17, 419-439.

Bezrukova, K., Jehn, K., Thatcher, S., \& Spell, C. (2012). The effects of alignments: Examining group faultlines, organizational cultures, and performance. Journal of Applied Psychology, 97, 77-92.

Bezrukova, K., Jehn, K., Zanutto, E., \& Thatcher, S. (2009). Do workgroup faultlines help or hurt? A moderated model of faultlines, team identification, and group performance. Organization Science, 20, 35-50.

Blau, P. (1977). Inequality and Heterogeneity: A Primitive Theory of Social Structure. New York: Free Press.

Brandon, D., \& Hollingshead, A. (2004). Transactive memory systems in organizations: Matching tasks, expertise, and people. Organization Science, 15, 633-644.

Bunderson, J. (2003). Recognizing and utilizing expertise in working groups: A status characteristics perspective. Administrative Science Quarterly, 48, 557-591.

Buyl, T., Boone, C., Hendriks, W., \& Matthyssens, P. (2011). TMT functional diversity and firm performance. The moderating role of CEO characteristics. Journal of Management Studies, 48, 151-177. 
Cannella, A., \& Monroe, M. (1997). Contrasting perspectives on strategic leaders: Toward a realistic view of top managers. Journal of Management, 23, 213-237.

Cannella, A., \& Holcomb, T. (2005). A multilevel analysis of the upper echelons model. In A. Dansereau and F. Yammarino, (Eds.), Multilevel issues in strategy and methods. Oxford: Elsevier.

Cannella, A., Park, J., \& Lee, H. (2008). Top management team functional background diversity and firm performance: Examining the roles of team member colocation and environmental uncertainty. Academy of Management Journal, 51, 768-784.

Cao, Q., Simsek, Z., \& Zhang, H. (2010). Modeling the joint impact of the CEO and the TMT on organizational ambidexterity, Journal of Management Studies, 47, 1272-1296.

Carmeli, A. \& Schaubroeck, J. (2006). Top management team behavioral integration, decision quality, and organizational decline. The Leadership Quarterly, 17, 441-453.

Carmeli, A., Gelbard, R., \& Reiter-Palmon, R. (2013). Leadership, creative problem-solving capacity, creative performance: The importance of knowledge sharing. Human Resource Management, 52, 95-122.

Carmeli, A., Schaubroeck, J., \& Tishler, A. (2011). How CEO empowering leadership shapes top management processes: Implications for firm performance. The Leadership Quarterly, 22, 399-411.

Carmeli, A., Tishler, A., \& Edmonson, A. (2012). CEO relational leadership and strategic decision quality in top management teams: The role of team trust and learning from failure. Strategic Organization, 10, 31-54.

Carpenter, M., Geletkanycz, M., \& Sanders, W. (2004). Upper echelons research revisited: Antecedents, elements and consequences of top management team composition. Journal of Management, 30, 749-778.

Carpenter, M., Sanders, W., \& Gregersen, H. (2001). Bundling human capital with organizational context: The impact of international assignment experience on multinational firm performance and CEO pay. Academy of Management Journal, 44, 493-511.

Carroll, G., \& Harrison, J. (1998). Organizational demography and culture: Insights from a formal model and simulation. Administrative Science Quarterly, 43, 637-667.

Carton, A., \& Cummings, J. (2012). A theory of subgroups in work teams. Academy of Management Review, 37, 441-470.

Chang, C., \& Johnson, R. (2010). Not all leader-member exchanges are created equal: Importance of leader relational identity. The Leadership Quarterly, 21, 796-808.

Chattopadhyay, P., Tluchowska, M., \& George, E. (2004). Identifying the ingroup: A closer look at the influence of demographic dissimilarity on employee social identity. Academy of Management Review, 29, 180-202.

Chung, S., \& Luo, X. (2013). Leadership Succession and firm performance in an emerging economy: Successor origin, relational embeddedness and legitimacy. Strategic Management Journal, 34, 338-357.

Cohen, J., Cohen, P., West, S. G., \& Aiken, L. (2003). Applied Multiple Regression/Correlation Analysis for Behavioral Sciences. Mahwah, N.J.: Lawrence Erlbaum Associates.

Cohen, W., \& Levinthal, D. (1990). Absorptive capacity: a new perspective on learning and innovation. Administrative Science Quarterly, 35, 128-152.

Cooper, D., Patel, P., \& Thatcher, S. (2014). It depends: Environmental context and the effects of faultlines on top management team performance. Organization Science, 25, 633-652.

Cortina, J. (1993). Interaction, nonlinearity, and multicollinearity: Implications for multiple regression. Journal of Management, 19, 915-922.

Crawford, E., \& LePine, J. (2013). A configural theory of team processes. Accounting for the structure of task-work and team-work. Academy of Management Review, 38, 32-48. 
Crossland, C., \& Hambrick, D. (2011). Differences in managerial discretion across countries: How national-level institutions affect the degree to which CEOs matter. Strategic Management Journal, 32, 797-819.

Crossland, C., Zyung, J., Hiller, N., \& Hambrick, D. (2014). CEO career variety: Effects on firm-level strategic and social novelty. Academy of Management Journal, 57, 652-667.

Crucke, S., \& Knockaert, M. (2016). When shareholder representation leads to faultlines: A study of board service performance in social enterprises. Journal of Management Studies, 53, 768-793.

Cyert R. \& March, J. (1963). A Behavioral Theory of the Firm. EC: Prentice-Hall.

Dahlin, K., Weingart, L., \& Hinds, P. (2005). Team diversity and information use. Academy of Management Journal, 48, 1107-1123.

Dai, Y., Roundy, P., Chok, J., Ding, F., \& Byun, G. (2016). Who knows what? in new venture teams: Transactive memory systems as a microfoundation of entrepreneurial orientation. Journal of Management Studies, 53, 1320-1347.

Daily, C., Certo, T., \& Dalton, D. (2000). International experience in the executive suite: The path to prosperity? Strategic Management Journal, 21, 515-523.

Dawson, J. F. (2014). Moderation in management research: What, why, when and how. Journal of Business and Psychology, 29, 1-19.

DeChurch, L., Hiller, N., Murase, T., Doty, D., \& Salas, E. (2010). Leadership across levels: Levels of leaders and their levels of impact. The Leadership Quarterly, 21, 1069-1085.

Dess, G., \& Beard, D. (1984). Dimensions of organizational task environments. Administrative Science Quarterly, 29, 52-73.

D'Innocenzo, L., Mathieu, J., \& Kukenberger, M. (2014). A meta-analysis of different forms of shared leadership-team performance relations. Journal of Management, 20, 1-28.

Dionne, S., Sayama, H., Hao, C., Bush, B. (2010). The role of leadership in shared model convergence and team performance improvement: An agent based computational model. The Leadership Quarterly, 21, 1035-1049.

Dragoni, L., Oh, I., Tesluk, P., Moore, O., VanKatwyk, P., \& Hazucha, J. (2014). Developing leaders' strategic thinking through global work experience: The moderating role of cultural distance. Journal of Applied Psychology, 99, 867-882.

Edwards, J. (2008). Seven deadly myths of testing moderation in organizational research. In C. Lance, \& R. Vandenberg (Eds.), Statistical and methodological myths and urban legends: Doctrine, verity and fable in the organizational and social sciences. NY: Routledge.

Ensley, M., Hmieleski, K., \& Pearce, C. (2006). The importance of vertical and shared leadership within new venture top management teams: Implications for the performance of startups. The Leadership Quarterly, 17, 217-231.

Epitropaki, O., Kark, R., Mainemelis, C., \& Lord, R. (2017). Leadership and followership identity processes: A multilevel review. The Leadership Quarterly, 28, 104-129.

Fischer, T., Dietz, J., \& Antonakis, J. Leadership process models: A review and synthesis. Journal of Management, In Press

Finkelstein, S., Hambrick, D., \& Cannella, A. (2009). Strategic Leadership: Theory and Research on Executives, Top management teams and boards. NY: Oxford University Press.

Fitzsimmons, T., \& Callan, V. (2016). CEO selection: A capital perspective. The Leadership Quarterly, 27, 765-787.

Friedman, Y., Carmeli, A., \& Tishler, A. (2016). How CEOs and TMTs build adaptive capacity in small entrepreneurial firms. Journal of Management Studies, 53, 996-1018.

Friedrich, T., Vessey, W., Schuelke, M., Ruark, G., \& Mumford, M. (2009). A framework for understanding collective leadership: The selective utilization of leader and team expertise within networks. The Leadership Quarterly, 20, 933-958.

Georgakakis, D., \& Ruigrok. W. (2017). CEO succession origin and firm performance: A multilevel study. Journal of Management Studies, 54, 58-87. 
Georgakakis, D., Dauth, T. \& Ruigrok, W. (2016). Too much of a good thing: Does international experience variety accelerate or delay executives' career advancement?' Journal of World Business, 51, 425-437.

Ghemawat, P., Depth index of internationalization (2013). http://www.ghemawat.com/dig/, Accessed: 09/11/2016.

Gibson, C. \& Vermeulen, F. (2003). A healthy divide: Subgroups as a stimulus for team learning behaviour. Administrative Science Quarterly, 48, 202-239.

Gratton, L., Voigt, A. \& Erickson, T. (2007). Bridging faultlines in diverse teams. MIT Sloan Management Review, 48, 22-29.

Greene, W. (2003). Econometric Analysis (5th ed.).Upper Saddle River, NJ: Prentice Hall.

Greve, P., Biemann, T., \& Ruigrok, W. (2015). Foreign executive appointments: A multilevel examination. Journal of World Business, 50, 674-686.

Guadalupe, M., Li, H. \& Wulf, J. (2014). Who lives in the C-Suite? Organizational structure and the division of labor in top management. Management Science, 60, 824-844.

Hambrick, D. (1994). Top management groups: A conceptual integration and reconsideration of the "team" label. In B. M. Staw and L.L. Cummings, (Ed.) Research in Organizational Behavior, 16, 171-213. Greenwich, CT: JAI Press.

Hambrick, D. (1995). Fragmentation and the other problems CEOs have with their top management teams. California Management Review, 37, 110-127.

Hambrick, D. (2007). Upper echelons theory: An update. Academy of Management Review, 32, 334-343.

Hambrick, D. \& Mason, P. (1984). Upper echelons: The organization as a reflection of its top managers. Academy of Management Journal, 15, 514-535.

Harrison, D., \& Klein, K. (2007). What's the difference? Diversity constructs as separation, variety or disparity in organizations. Academy of Management Review, 32, 1199-1228.

Harrison, D., Price, K., Gavin, J. \& Florey, A. (2002). Time, teams, and task performance: Changing effects of diversity on group functioning. Academy of Management Journal, 45, 1029-1045.

Heyden, M.L.M., Oehmichen, J., Volberda, H. \& Nichting, S. (2015). Board Background Heterogeneity and Exploration-Exploitation: The Role of the Institutionally Adopted Board Model. Global Strategy Journal, 5, 154-176.

Heyden, M.L.M., Fourne, S.P.L., Koene, B.A.S., Werkman, R. \& Ansari, S. Rethinking Topdown and Bottom-up Roles of Top and Middle Managers in Organizational Change: Implications for Employee Support. Journal of Management Studies, DOI: 10.1111/joms.12258. In Press.

Hiller, N., DeChurch, L., Murase, T., \& Doty, D. (2011). Searching for outcomes of leadership: A 25-year review. Journal of Management, 37, 1137-1177.

Hirst, G., van Dick, R., \& van Knippenberg, D. (2009). A social identity perspective on leadership and employee creativity. Journal of Organizational Behavior, 30, 963-982.

Hmieleski, K., Cole, M., \& Baron, R. (2012). Shared authentic leadership and new venture performance. Journal of Management, 38, 1476-1499.

Hoch, J. (2013). Shared leadership and innovation: The role of vertical leadership and employee integrity. Journal of Business and Psychology, 28, 159-174.

Hoever, I., van Knippenberg, D., van Ginkel, W., \& Barkema, H. (2012). Fostering team creativity: Perspective taking as key to unlocking diversity's potential. Journal of Applied Psychology, 97, 982-996.

Hogg, M.A., (2001). A social identity theory of leadership. Personality and Social Psychology Review, 3, 184-200.

Hornsey, M., \& Hogg, M. (2000). Assimilation and diversity: An integrative model of subgroup relations. Personality and Social Psychology Review, 4, 143-156. 
Hutzschenreuter, T., \& Horstkotte, J. (2013). Performance effects of top management team demographic faultlines in the process of product diversification. Strategic Management Journal, 34, 704-726.

Jackson, S. (1992). Consequences of group composition for the interpersonal dynamics of strategic issue processing. In P. Shrivastava, A. Huff and J. Dutton (Eds.) Advances in Strategic Management, 8, 345-389, London, UK: JAI Press.

Jacobs, T. \& McGee, M. (2001). Competitive advantage: Conceptual imperatives for executives. In S. Zaccaro, \& R. Klimoski (Eds.), The Nature of Organizational Leadership: Understanding the Performance Imperatives Confronting Today's Leaders. CA: JosseyBass.

Joshi, A. \& Roh, H. (2009). The role of context in work team diversity research: A metaanalytic review. Academy of Management Journal, 52, 599-627.

Kanfer, R., Ackerman, P., Murtha, T., Dugdale, B. \& Nelson, L. (1994). Goal setting, conditions of practice, and task performance: A resource allocation perspective. Journal of Applied Psychology, 79, 826-835.

Karaevli, A. \& Hall, D. (2006), How career variety promotes the adaptability of managers? A theoretical model. Journal of Vocational Behavior, 69, 359-373.

Kearney, E., \& Gebert, D. (2009). Managing diversity and enhancing team outcomes: The promise of transformational leadership. Journal of Applied Psychology, 94, 77-89.

Klein, K., Ziegert, J., Knight, A., \& Xiao, Y. (2006). Dynamic delegation: Shared, hierarchical, and deindividualized leadership in extreme action teams. Administrative Science Quarterly, 51, 590-621.

Klimoski, R., \& Koles, K. (2001). The chief executive officer and top management team interface. In Zaccaro, S. \& Klimoski, R. (Eds.), The Nature of Organizational Leadership: 219-269. CA: Jossey-Bass.

Kunze, F., de Jong, S., \& Bruch, H. (2016). Consequences of collective-focused leadership and differentiated individual focused leadership: Development and testing of an organizational level model. Journal of Management, 42, 886-914.

Lau, D., \& Murnighan, J. (1998). Demographic diversity and faultlines: The compositional dynamics of organizational groups. Academy of Management Review, 23, 325-340.

Lawrence, B. (1997). The black box of organizational demography. Organization Science, 8 , $1-22$.

Li, J., \& Hambrick, D. (2005). Factional groups: A new vantage on demographic faultlines, conflict, and disintegration in work teams. Academy of Management Journal, 48, 794-813.

Lim, J. Busenitz, L., \& Chidambaram, L. (2013). New venture teams and the quality of business opportunities identified: Faultlines between subgroups of founders and investors. Entrepreneurship Theory and Practice, 37, 47-67.

Lin, H., \& Rababah, N. (2014). CEO-TMT exchange, TMT personality composition, and decision quality: The mediating role of TMT psychological empowerment. The Leadership Quarterly, 25, 943-957.

Ling, Y., Simsek, Z., Lubatkin, M., \&. Veiga, J. (2008). Transformational leadership`s role in promoting corporate entrepreneurship: Examining the CEO-TMT interface. Academy of Management Journal, 51, 557-576.

Mäs, M., Flache, A., Takàcs, K., \& Jehn, K. (2013). In the short term we divide, in the long term we unite: Demographic crisscrossing and the effects of faultlines on subgroup polarization. Organization Science, 24, 716-736.

Mathieu, J., Heffner, T., Goodwin, G., Salas, E. \& Cannon-Bowers, J. (2000). The influence of shared metal models on team process and performance. Journal of Applied Psychology, 85, 273-283.

Menz, M. (2012). Functional top management team members: A review, synthesis, and research agenda. Journal of Management, 38, 45-80. 
Mesmer-Magnus, J., \& DeChurch, L. (2009). Information sharing and team performance: A meta-analysis. Journal of Applied Psychology, 94, 536-546.

Meyer, B. \& Glenz (2013). Team faultline measures: A computational comparison and a new approach to multiple subgroups. Organizational Research Methods, 16, 393-424.

Meyer, B., Shemla, M., Li, J. \& Wegge, J. (2015). On the same side of the faultline: Inclusion in the leader's subgroup and employee performance. Journal of Management Studies, 52, 354-380.

Michel, J. \& Hambrick, D. (1992). Diversification posture and top management team characteristics. Academy of Management Journal, 35, 9-37.

Milliken, F. \& Martins, L. 1996. Searching for common threads: Understanding the multiple effects of Diversity in Organizational Groups. Academy of Management Review, 21: 402433.

Minbaeva, D., Pedersen, T., Björkman, I., Fey, C., \& Park, H. (2014). MNC knowledge transfer subsidiary absorptive capacity and HRM. Journal of International Business Studies, 45, 3851.

Mitchell, R., Boyle, B., Parker, V., Giles, M., Chiang, V., \& Joyce, P. (2015). Managing Inclusiveness and Diversity in Teams: How Leader Inclusiveness Affects Performance through Status and Team Identity. Human Resource Management, 54, 217-239.

Ndofor, H., Sirmon, D., He, X. (2014). Utilizing the firm's resources: How TMT heterogeneity and resulting faultlines affect TMT tasks? Strategic Management Journal, 36, 1656-1674.

Oehmichen, J., Heyden, M.L.M., Georgakakis, D. \& Volberda, H.W. (2017). Board of Directors and Organizational Ambidexterity in Knowledge Intensive Firms. International Journal of Human Resource Management, 28, 283-306.

Pearce, C., \& Sims, H. (2002). Vertical versus shared leadership as predictors of the effectiveness of change management teams: An examination of aversive, directive, transactional, transformational, and empowering leader behaviors. Group Dynamics: Theory, Research, and Practice, 6, 172-197.

Pearce, C., Conger, J. \& Locke, E. (2007). Shared leadership theory. The Leadership Quarterly, 19, 622-628.

Pegels, C., Song, Y., \& Yang, B. (2000). Management heterogeneity, competitive interaction groups, and firm performance. Strategic Management Journal, 21, 911-923.

Peterson, R., Smith, D., Martorana, P. \& Owens, P. (2003). The impact of chief executive officer personality on top management team dynamics: One mechanism by which leadership affects organizational performance. Journal of Applied Psychology, 88, 795-808.

Polzer, J., Crisp, C., Jarvenpaa, S., \& Kim, J., (2006). Extending the faultlines model to geographically dispersed teams: How collocated subgroups can impair group functioning. Academy of Management Journal, 49, 679-692.

Rico, R., Sanchez-Manzanares, M., Mirko, A., \& Lau, D. (2012). Bridging team faultlines by combining task role assignment and goal structure strategies. Journal of Applied Psychology, 97, 407-420.

Rodan, S., \& Galunic, D. (2004). More than network structure: how knowledge heterogeneity influences managerial performance and innovativeness. Strategic Management Journal, 25, 541-556.

Roth, K. (1995). Managing international interdependence: CEO characteristics in a resourcebased framework. Academy of Management Journal, 38, 200-231.

Shen, W., \& Cannella, A.A. (2002). Revisiting the performance consequences of CEO succession: The impact on successor type, post succession senior executive turnover, and departing CEO tenure. Academy of Management Journal, 45, 717-733.

Simsek, Z., Jansen, J., Minichilli, A., \& Escriba-Esteve, A. (2015). Strategic leadership and leaders in entrepreneurial contexts: A nexus for innovation and impact missed? Journal of Management Studies, 52, 463-478. 
Strasser, G., \& Titus, W. (1985). Pooling of unshared information in group decision making: Biased information sampling during discussion. Journal of Personality and Social Psychology, 48, 1467-1478.

Tajfel, H. (1978). The achievement of group differentiation. In H. Tajfel (Ed.) Differentiation Between Social Groups: Studies in the Social Psychology of Intergroup Relations. London: Academic Press.

Taylor, A., \& Greve, H. (2006). Superman or the fantastic four? Knowledge combination and experience in innovative teams. Academy of Management Journal, 49, 723-740.

Thatcher, S., \& Patel, P. (2012). Group faultlines: A review, integration, and guide to future research. Journal of Management, 38, 969-1009.

Thatcher, S., Jehn, K., \& Zanutto, E. (2003). Cracks in diversity research: The effects of diversity faultlines on conflict and performance. Group Decision and Negotiation, 12, 217241.

Tsui, A. S., Egan, T. D., \& O’Reilly, C. A. (1992). Being different: Relational demography and organizational attachment. Administrative Science Quarterly, 37, 549-579.

Turner, J. C. (1987). Rediscovering the Social Group: A Social Categorization Theory. Oxford, Blackwell.

Tuggle, C. Schnatterly, K., \& Johnson, R. (2010). Attention patterns in the boardroom: How board composition and processes affect discussion to entrepreneurial issues. Academy of Management Journal, 53, 550-571.

Uhl-Bien, M., Marion, R., \& McKelvey, B. (2007). Complexity leadership theory: Shifting leadership from the industrial age to the knowledge era. The Leadership Quarterly, 18, 298318.

van Knippenberg, D., Dawson, D., West, J., \& Homan, A. (2011). Diversity faultlines, shared objectives, and top management team performance. Human Relations, 64, 307-336.

van Knippenberg, D., de Dreu, C., \& Homan, A. (2004). Work group diversity and group performance: An integrative model and research agenda. Journal of Applied Psychology, 89, 1008-1022.

Veltrop, D., Hermes, N., Postma, T., \& de Haan, J. (2015). A tale of two factions: Why and when factional demographic faultlines hurt firm board performance? Corporate Governance: An International Review, 23, 145-160.

Waismel-Manor, R., Tziner, A., Berger, E., \& Dikstein, E. (2010). Two of a kind? Leadermember exchange and organizational citizenship behaviors: The moderating role of leadermember similarity. Journal of Applied Psychology, 40, 167-181.

Wang, P., \& Rode, J. (2010). Transformational leadership and follower creativity: The moderating effects of identification with leader and organizational climate. Human Relations, 63, 1105-1128.

Wangrow, D, Schepker, D., \& Barker, V. (2015). Managerial discretion: An empirical review and future research directions. Journal of Management, 41, 99-135.

Westphal, J., \& Zajac, E. (1995). Who shall govern? CEO/Board power, demographic similarity, and new director selection. Administrative Science Quarterly, 40, 60-83.

World Federation of Exchanges, www.world-exchanges.org/home/ (2013). Accessed $09 / 11 / 2016$

Xie, X., Wang, L., \& Qi, Z., (2015). The effects of TMT faultlines configuration on firm's short term performance and innovation activities. Journal of Management and Organization, 21, 558-572.

Yammarino, F., Dionne, S., Chun, J., Dansereau, F. (2005). Leadership and levels of analysis: A state-of-the-science review. The Leadership Quarterly, 16, 879-919.

Yoshida, D., Sendjaya, S., Hirst, G., \& Cooper, B. (2014). Does servant leadership foster creativity and innovation? A multi-level mediation study of identification and prototypicality. Journal of Business Research, 67, 1396-1404. 
Yukl, G. (2008). How leaders influence organizational effectiveness. The Leadership Quarterly, 19, 708-722.

Zaccaro, S., \& Klimoski, R. (2001). The nature of organizational leadership: An introduction. In S. Zaccaro \& R. Klimoski (Eds.), The nature of organizational leadership: Understanding the performance imperatives confronting today's leaders: 3-41. San Francisco: Jossey-Bass. 
TABLE 1

Descriptive statistics and correlations

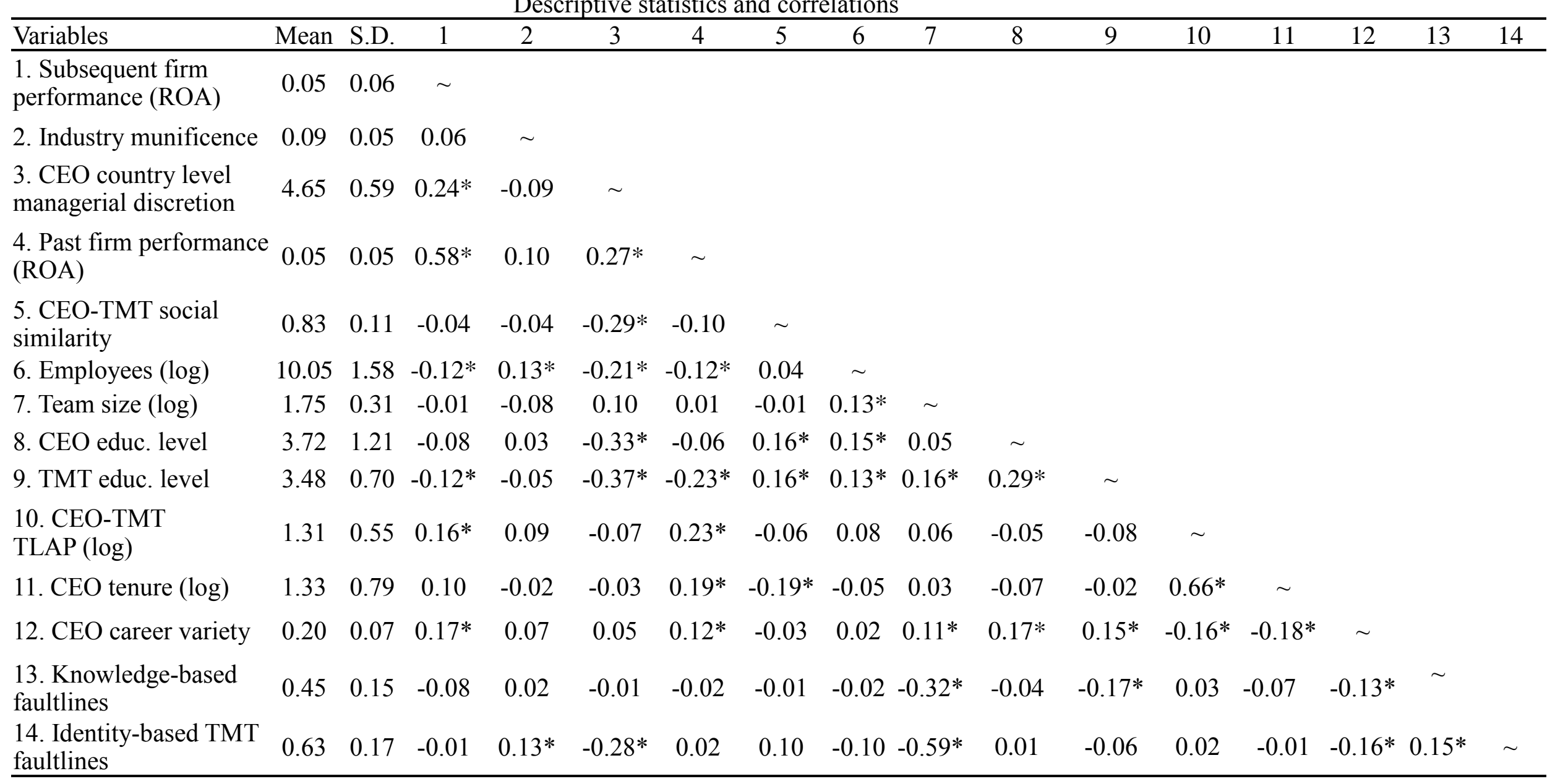

$* \mathrm{p}<0.05$ 
Table 2. GLS analysis with firm performance as dependent variable

\begin{tabular}{|c|c|c|c|c|c|}
\hline & Model 1 & Model 2 & Model 3 & Model 4 & Model 5 \\
\hline Intercept & $\begin{array}{l}-0.06 \\
(0.05)\end{array}$ & $\begin{array}{l}-0.02 \\
(0.06)\end{array}$ & $\begin{array}{l}0.12 \\
(0.11)\end{array}$ & $\begin{array}{l}0.24^{*} \\
(0.12)\end{array}$ & $\begin{array}{l}0.36^{* *} \\
(0.12)\end{array}$ \\
\hline $\begin{array}{l}\text { Industry } \\
\text { Munificence }\end{array}$ & $\begin{array}{l}0.00 \\
(0.06)\end{array}$ & $\begin{array}{l}-0.00 \\
(0.06)\end{array}$ & $\begin{array}{l}0.00 \\
(0.06)\end{array}$ & $\begin{array}{l}-0.00 \\
(0.06)\end{array}$ & $\begin{array}{l}-0.01 \\
(0.06)\end{array}$ \\
\hline $\begin{array}{l}\text { CEO country level } \\
\text { managerial } \\
\text { discretion }\end{array}$ & $\begin{array}{l}0.01^{*} \\
(0.01)\end{array}$ & $\begin{array}{l}0.01^{*} \\
(0.01)\end{array}$ & $\begin{array}{l}0.01 \dagger \\
(0.01)\end{array}$ & $\begin{array}{l}0.01 * \\
(0.01)\end{array}$ & $\begin{array}{l}0.01 * \\
(0.01)\end{array}$ \\
\hline Year dummies & included & included & included & included & included \\
\hline $\begin{array}{l}\text { Past firm } \\
\text { performance (ROA) }\end{array}$ & $\begin{array}{l}0.55^{* * * *} \\
(0.06)\end{array}$ & $\begin{array}{l}0.55^{* * * *} \\
(0.06)\end{array}$ & $\begin{array}{l}0.54 * * * \\
(0.06)\end{array}$ & $\begin{array}{l}0.53 * * * \\
(0.06)\end{array}$ & $\begin{array}{l}0.57 * * * \\
(0.06)\end{array}$ \\
\hline $\begin{array}{l}\text { CEO-TMT social } \\
\text { similarity }\end{array}$ & $\begin{array}{l}0.03 \\
(0.03)\end{array}$ & $\begin{array}{l}0.03 \\
(0.03)\end{array}$ & $\begin{array}{l}-0.13 \\
(0.10)\end{array}$ & $\begin{array}{l}-0.19 \dagger \\
(0.10)\end{array}$ & $\begin{array}{l}-0.22^{*} \\
(0.10)\end{array}$ \\
\hline Employees (log) & $\begin{array}{l}-0.00 \\
(0.00)\end{array}$ & $\begin{array}{l}-0.00 \\
(0.00)\end{array}$ & $\begin{array}{l}-0.00 \\
(0.00)\end{array}$ & $\begin{array}{l}-0.00 \\
(0.00)\end{array}$ & $\begin{array}{l}-0.00 \\
(0.00)\end{array}$ \\
\hline TMT size (log) & $\begin{array}{l}-0.01 \\
(0.01)\end{array}$ & $\begin{array}{l}-0.02 \\
(0.01)\end{array}$ & $\begin{array}{l}-0.02 \\
(0.01)\end{array}$ & $\begin{array}{l}-0.02 \dagger \\
(0.01)\end{array}$ & $\begin{array}{l}-0.02 \dagger \\
(0.01)\end{array}$ \\
\hline CEO educ. level & $\begin{array}{l}-0.00 \\
(0.00)\end{array}$ & $\begin{array}{l}-0.00 \\
(0.00)\end{array}$ & $\begin{array}{l}-0.00 \\
(0.00)\end{array}$ & $\begin{array}{l}-0.00 \\
(0.00)\end{array}$ & $\begin{array}{l}-0.00 \\
(0.00)\end{array}$ \\
\hline $\begin{array}{l}\text { TMT educ. level } \\
\text { average }\end{array}$ & $\begin{array}{l}0.01 \\
(0.00)\end{array}$ & $\begin{array}{l}0.01 \\
(0.00)\end{array}$ & $\begin{array}{l}0.01 \\
(0.00)\end{array}$ & $\begin{array}{l}0.00 \\
(0.00)\end{array}$ & $\begin{array}{l}0.01 * \\
(0.00)\end{array}$ \\
\hline $\begin{array}{l}\text { CEO-TMT TLAP } \\
(\log )\end{array}$ & $\begin{array}{l}0.01 * \\
(0.01)\end{array}$ & $\begin{array}{l}0.02 * \\
(0.01)\end{array}$ & $\begin{array}{l}0.02 * \\
(0.01)\end{array}$ & $\begin{array}{l}0.02 * \\
(0.01)\end{array}$ & $\begin{array}{l}-0.06 * * \\
(0.02)\end{array}$ \\
\hline CEO tenure (log) & $\begin{array}{l}-0.01 \\
(0.00)\end{array}$ & $\begin{array}{l}-0.01 \\
(0.00)\end{array}$ & $\begin{array}{l}-0.01 \\
(0.00)\end{array}$ & $\begin{array}{l}-0.01 \\
(0.00)\end{array}$ & $\begin{array}{l}-0.01 \dagger \\
(0.00)\end{array}$ \\
\hline CEO career variety & $\begin{array}{l}0.09^{*} \\
(0.04)\end{array}$ & $\begin{array}{l}0.08 \dagger \\
(0.04)\end{array}$ & $\begin{array}{l}0.08 \dagger \\
(0.04)\end{array}$ & $\begin{array}{l}-0.22 \dagger \\
(0.13)\end{array}$ & $\begin{array}{l}-0.34^{* *} \\
(0.13)\end{array}$ \\
\hline $\begin{array}{l}\text { Knowledge-based } \\
\text { faultlines }\end{array}$ & & $\begin{array}{l}-0.04 * \\
(0.02)\end{array}$ & $\begin{array}{l}-0.34 \dagger \\
(0.18)\end{array}$ & $\begin{array}{l}-0.60 * * \\
(0.21)\end{array}$ & $\begin{array}{l}-0.89 * * * \\
(0.22)\end{array}$ \\
\hline $\begin{array}{l}\text { Identity-based } \\
\text { faultlines }\end{array}$ & & $\begin{array}{l}-0.01 \\
(0.02)\end{array}$ & $\begin{array}{l}-0.01 \\
(0.02)\end{array}$ & $\begin{array}{l}-0.01 \\
(0.02)\end{array}$ & $\begin{array}{l}-0.01 \\
(0.02)\end{array}$ \\
\hline $\begin{array}{l}\text { Knowledge-based } \\
\text { faultlines X CEO- } \\
\text { TMT similarity }\end{array}$ & & & $\begin{array}{l}0.36 \dagger \\
(0.22)\end{array}$ & $\begin{array}{l}0.50 * \\
(0.22)\end{array}$ & $\begin{array}{l}0.55^{*} \\
(0.22)\end{array}$ \\
\hline $\begin{array}{l}\text { Knowledge-based } \\
\text { faultlines X CEO } \\
\text { exp. variety }\end{array}$ & & & & $\begin{array}{l}0.71^{*} \\
(0.29)\end{array}$ & $\begin{array}{l}0.90 * * \\
(0.29)\end{array}$ \\
\hline $\begin{array}{l}\text { Knowledge-based } \\
\text { faultlines X CEO- } \\
\text { TMT TLAP }\end{array}$ & & & & & $\begin{array}{l}0.15 * * * \\
(0.04)\end{array}$ \\
\hline $\mathrm{R}^{2}$ & 0.41 & 0.42 & 0.42 & 0.43 & 0.45 \\
\hline Wald $\mathrm{Chi}^{2}$ & $163.6^{* * *}$ & $168.6 * * *$ & $167.2 * *$ & $173.2 * * *$ & $195.2 * * *$ \\
\hline
\end{tabular}


Figure 1. Research Framework

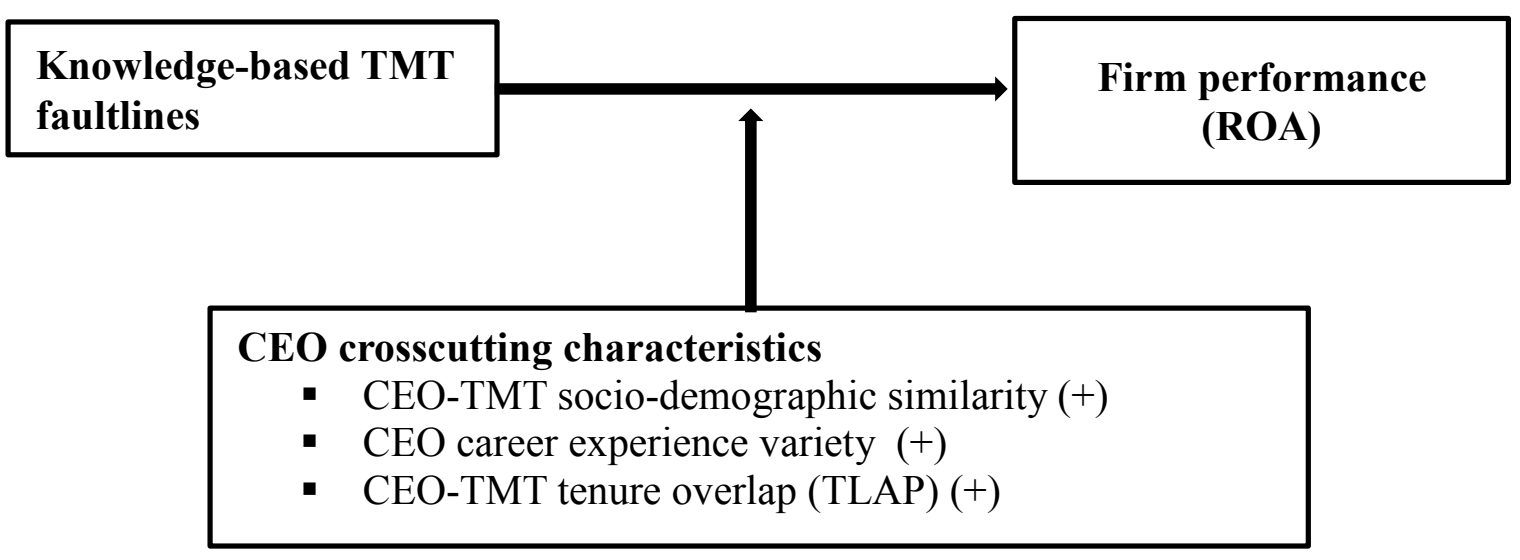

Figure 2. Moderating effects of CEO-TMT social similarity

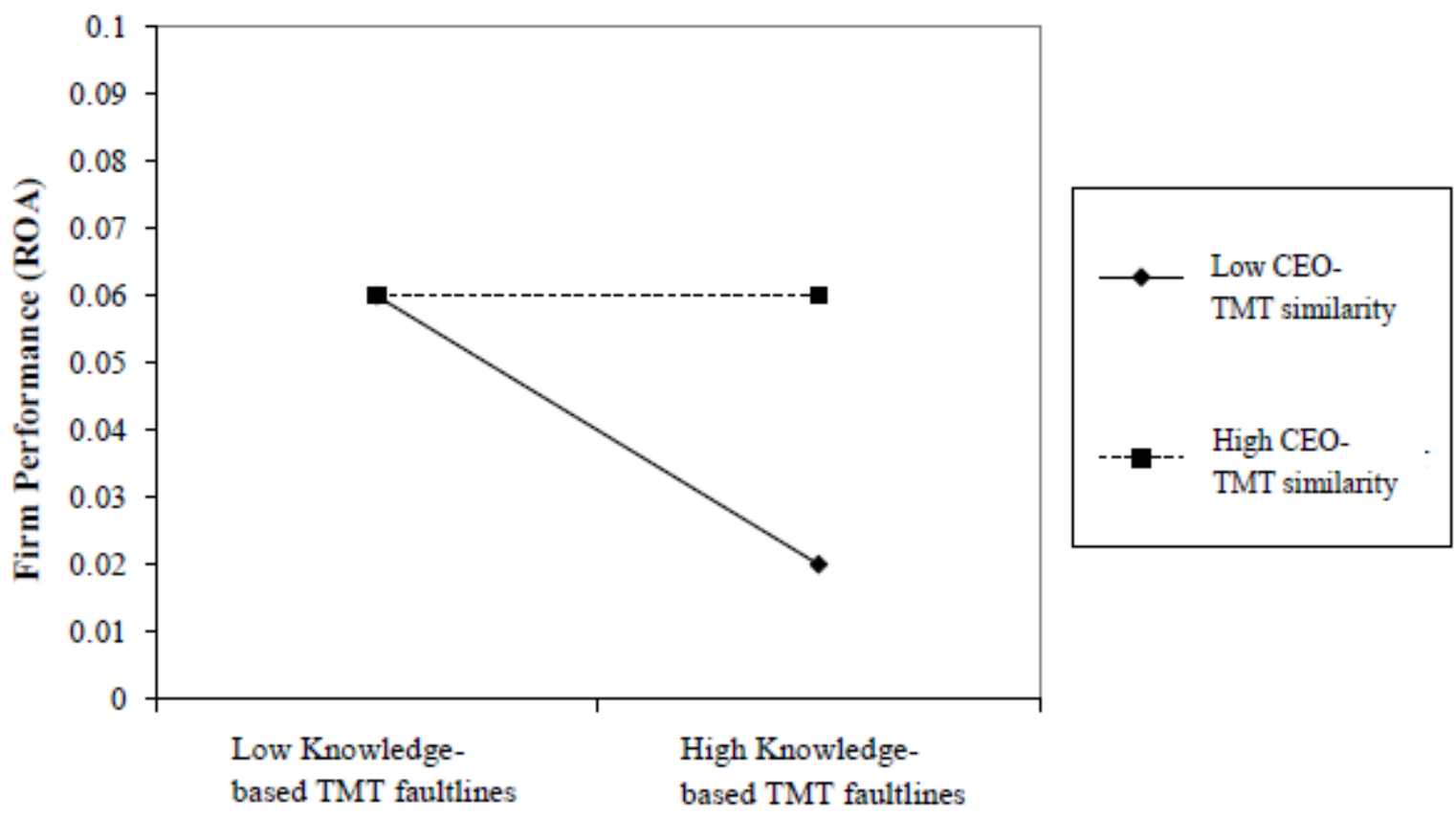


Figure 3. Moderating effects of CEO experience variety

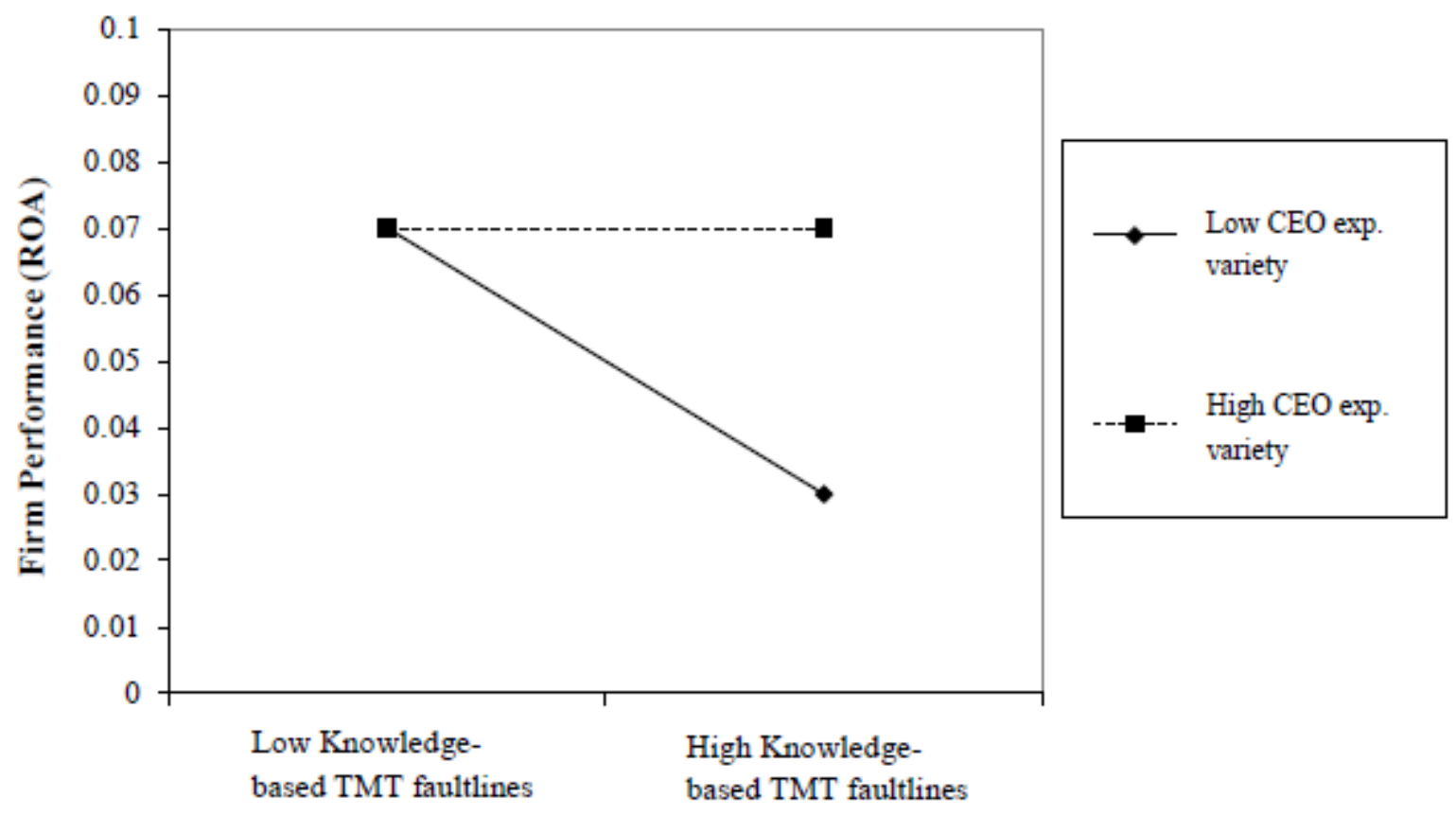

Figure 4. Moderating effects of CEO-TMT shared experience

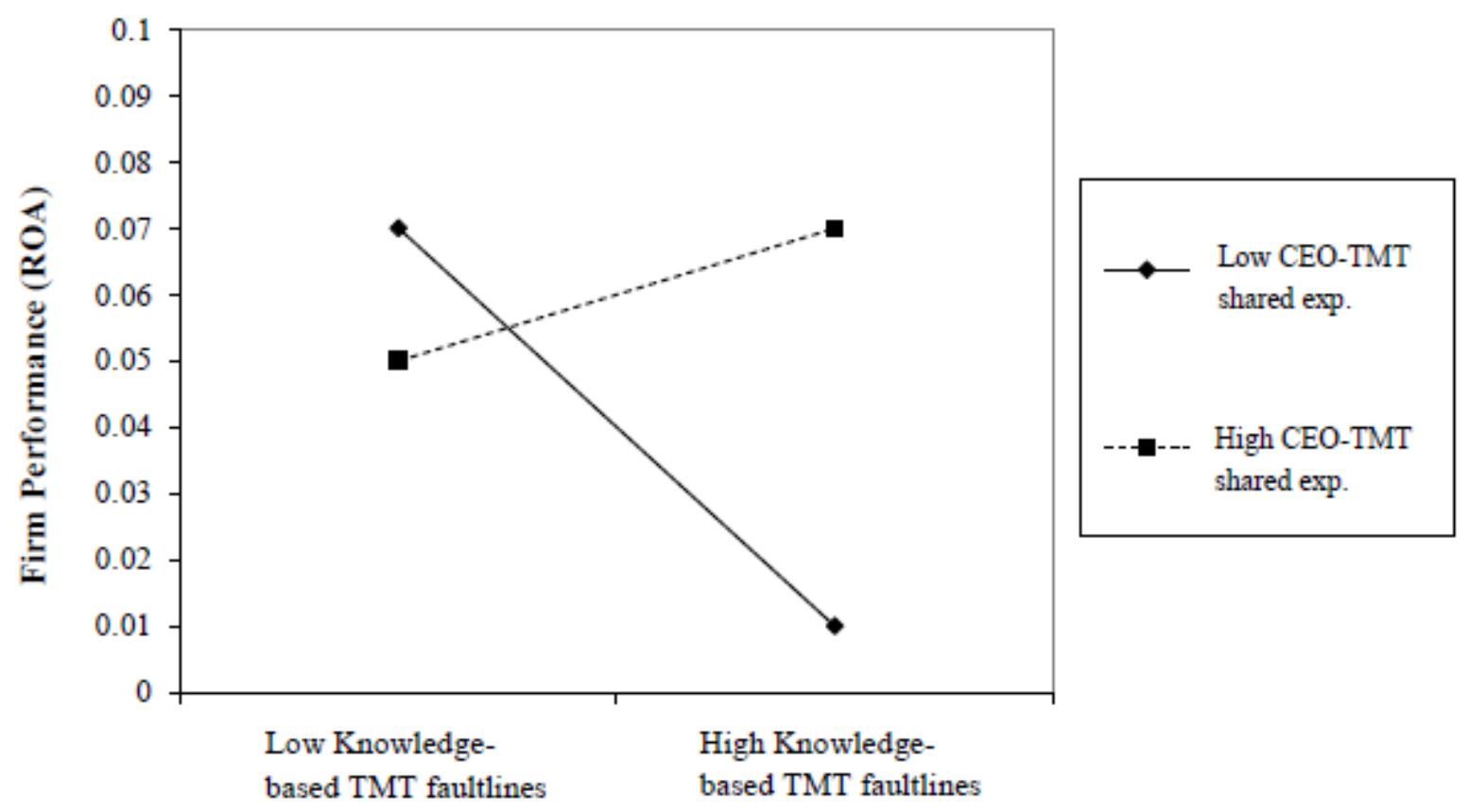

